\title{
A molecular phylogenetic approach to the New Zealand species of Enantiobuninae (Opiliones: Eupnoi : Neopilionidae)
}

\section{Citation}

Vélez, Sebastián, Rosa Fernández, and Gonzalo Giribet. 2014. “A Molecular Phylogenetic Approach to the New Zealand Species of Enantiobuninae (Opiliones\#: Eupnoi\#: Neopilionidae)." Invertebrate Systematics 28, no. 6: 565-589. doi:10.1071/IS14030

\section{Published Version}

doi:10.1071/IS14030

\section{Permanent link}

http://nrs.harvard.edu/urn-3:HUL.InstRepos:14425988

\section{Terms of Use}

This article was downloaded from Harvard University's DASH repository, and is made available under the terms and conditions applicable to Open Access Policy Articles, as set forth at http:// nrs.harvard.edu/urn-3:HUL.InstRepos:dash.current.terms-of-use\#OAP

\section{Share Your Story}

The Harvard community has made this article openly available.

Please share how this access benefits you. Submit a story.

\section{Accessibility}


1 A molecular phylogenetic approach to the New Zealand species of Enantiobuninae

2 (Opiliones : Eupnoi : Neopilionidae)

3

4 Sebastián Vélez ${ }^{\mathrm{A}, \mathrm{B}, \mathrm{C}}$, Rosa Fernández ${ }^{\mathrm{A}}$, and Gonzalo Giribet ${ }^{\mathrm{A}}$

$6 \quad{ }^{\text {A }}$ Museum of Comparative Zoology, Department of Organismic and Evolutionary

7 Biology, Harvard University, 26 Oxford Street, Cambridge, MA 02138, USA.

$8{ }^{\mathrm{B}}$ Current address: Biology Department, Worcester State University, 486 Chandler Street,

9 Worcester, MA 01602, USA.

$10 \quad{ }^{\mathrm{C}}$ Corresponding author. Email:svelez@worcester.edu

11

12 Running title: Phylogenetics of the New Zealand Enantiobuninae 
13 Abstract. We report the first phylogeny based on molecular data for the New

14 Zealand species in the genera Forsteropsalis, Pantopsalis, and Mangatangi, and

15 comment on the taxonomic implications of our results, including the diagnostic viability

16 of important morphological characters. Members of the New Zealand Enantiobuninae

17 constitute some of the most charismatic soil arthropods of the archipelago, and a striking

18 example of sexual dimorphism, with nondescript females but colourful males boasting

19 exaggerated chelicerae many times longer than their bodies. The genera Forsteropsalis

20 and Pantopsalis recently underwent revision, but many questions remained about the

21 validity of many species designations, due to issues of characters of dubious taxonomic

22 value, female specimens designated as holotypes despite the males holding all the

23 diagnostic characters, and the suspected presence of more than one male form within

24 some species. We present the first molecular phylogenetic study of the group, including

25 extensive sampling of fresh material across New Zealand. Our results reject the

26 controversial monophyly of Neopilionidae and comment on the taxonomic implications

27 of the results, including the diagnostic validity of morphological characters traditionally

28 used on the groups.

30 The following taxonomic action is taken: Forsteropsalis nigra is considered a junior

31 synonym of Forsteropsalis inconstans (new synonymy).

33 Additional keywords: Monoscutidae, Australia, biogeography, phylogeny 


\section{Introduction}

35 The order Opiliones consists of 6,539 described species (Kury 2013), divided into four

36 suborders, 45 families and about 1,500 genera (Machado, Pinto-da-Rocha et al. 2007;

37 Sharma and Giribet 2011; Sharma, Prieto et al. 2011; Pinto-da-Rocha, Bragagnolo et al.

38 2014), with many new species being described every year. Within Opiliones, the

39 suborder Eupnoi includes the superfamilies Caddoidea and Phalangioidea (Shear 1982).

40 The first group, Phalangioidea, forms a monophyletic assemblage of those eupnoids with

41 long legs and smooth palps (Shultz 1998; Giribet, Rambla et al. 1999; Shultz and Regier

42 2001; Giribet, Edgecombe et al. 2002; e.g., Giribet, Vogt et al. 2010). Phalangioidea is

43 divided into the families (1) Phalangiidae Latreille, 1802, of nearly world-wide

44 distribution, and which includes the cosmopolitan "daddy-longleg" or common

45 harvestman, Phalangium opilio Linnaeus, 1758; (2) Sclerosomatidae Simon, 1879, a

46 speciose family with more than 1,300 species and many more to be described in dense

47 subtropical forests (Machado, Pinto-da-Rocha et al. 2007); (3) Protolophidae Banks,

481893 (Cokendolpher 2007b); (4) Monoscutidae Forster, 1948, as prior to Taylor (2011)

49 and as discussed below, from New Zealand and Australia; and (5) Neopilionidae

50 Lawrence, 1931 with a temperate Gondwanan distribution: New Zealand, Australia,

51 South Africa and South America, and diagnosed by the penis morphology (Hunt and

52 Cokendolpher 1991b). The current work is concerned with the last two, Monoscutidae

53 and Neopilionidae.

54 Prior to Taylor (2011) work on Neopilionidae included, among others, the families

55 (1) Neopilionidae, with 8 genera and 15 species from South Africa (including Neopilio

56 australis), Australia and South America, and (2) Monoscutidae Forster, 1948 with 5 
57 genera and 32 species found in Australia and New Zealand (Fig. 1). The 8 genera within

58 Neopilionidae were divided into three subfamilies: (1) Neopilioninae Lawrence, 1931,

59 with a single species from South Africa; (2) Enantiobuninae Mello-Leitão, 1931 with

60 four South American species; and (3) the larger group Ballarrinae Hunt \& Cokendolpher,

61 1991, which included mostly species from Australia, one from Chile, and one from South

62 America. Monoscutidae was divided into: (1) Monoscutinae Forster, 1948, from New

63 Zealand and having heavy sclerotization and small ozopores; and (2) Megalopsalidinae

64 Forster, 1949, characterized by a smooth carapace, except for small spines in some, e.g.,

65 Forsteropsalis nigra (Forster, 1944) and F. inconstans (Forster, 1944), and by the

66 presence of visible ozopores, and which contained Megalopsalis (Australia and New

67 Zealand), Pantopsalis Simon, 1879, (New Zealand endemic), and Spinicrus Forster, 1949

68 (Australia) (Cokendolpher 2007a; Cokendolpher and Taylor 2007b).

69 The New Zealander and Australian species of Eupnoi also show a striking sexual

70 polymorphism with conspicuously enlarged male chelicerae, and nondescript females

71 (Fig. 2). The long chelicerae in the males can reach up to 10 times the length of the body,

72 comically extending high above the individual, and which in some cases also have

73 grossly enlarged second segments that rival the girth of the main body of the animal, e.g.,

74 Forsteropsalis fabulosa (Phillips \& Grimmett, 1932) and Megalopsalis turneri Marples,

751944 (Forster 1944b; Marples 1944; Forster 1949b; Forster and Wilton 1968; Forster and

76 Forster 1999; Taylor 2004a; Taylor 2011). This presence of sexual dimorphism, and the

77 dearth of characters in the female chelicerae in Pantopsalis, Forsteropsalis, and

78 Megalopsalis are largely responsible for the taxonomic instability of the species in each

79 genus (Figs. 3, 4) . Females in both Pantopsalis and Forsteropsalis have a uniform brown 
80 colour, with almost identical markings, so most species descriptions have been based on

81 males, and females have been assigned to species when they are collected in close

82 proximity to an identifiable male, which is not free of error, as it is common to collect

83 specimens of different species in close proximity (see also Fernández et al. submitted).

84 As an example of the confusion this has caused, in 1949 Forster corrected Pocock's

85 (1902a) purported Megalopsalis hoggi female as the male of Spinicrus camelus, although

86 a few years earlier, Forster himself had described Megalopsalis luna from a specimen

87 which Taylor later assigned to a Pantopsalis female (Forster 1944b; Taylor 2004a),

88 something that Forster must have noticed in his original description of the female of

89 Pantopsalis mila, which matches his own description of the Megalopsalis luna male

90 (Forster 1964b). Taylor (2004) also reported that Pocock described a male of Pantopsalis

91 jenningsi as a female of Pantopsalis nigripalpis, something that Pocock himself corrected

92 a year later (Pocock 1903a; Taylor 2011). In addition to sexual dimorphism, male

93 dimorphism has also been reported, with some species purportedly having distinct broad-

94 chelicerae and a long-chelicerae male forms, which have been dubbed the 'normal' and

95 'effeminate' forms (Forster 1964b; Taylor 2004a). In light of this, and in apparent

96 frustration, Forster (1965) spelled out the rampant taxonomic confusion brought by

97 sexual dimorphism, with what he saw as different authors describing species

98 independently from males and females, and ended the description of several new species

99 with a note that he would not attempt a key for Monoscutidae of New Zealand until the

100 issue of assigning males to females had been resolved (Forster 1962b). Lacking breeding

101 experiments or molecular studies (but see Fernández et al. submitted), it is unknown if

102 the forms belong to the same species, and if they do, how many species have either or 
103 both forms, or if the forms are in discrete categories or occupy a range of sizes and

104 variants, as reported by Kauri (1954) for Spinicrus minimus. If true, this could mean that

105 the current designations are just an artefact from poor sampling from a highly

106 polymorphic population.

107

108 Although the phylogeny of the order Opiliones has received substantial attention

109 in the past decades (Giribet, Rambla et al. 1999; Giribet and Wheeler 1999; Shultz and

110 Regier 2001; Giribet, Edgecombe et al. 2002; Giribet and Kury 2007; Giribet, Vogt et al.

111 2010), only recently Giribet et al. (2010) published the first molecular sequences that

112 included members of the new Enantiobuninae (former Monoscutidae), although the

113 sampling and analysis was only in the context of the broader phylogenetic relationships

114 of the whole order Opiliones. Here we report the first comprehensive molecular

115 systematics study of the New Zealand species currently assigned to Enantiobuninae,

116 based on freshly collected material from New Zealand, Australia and South Africa, and in

117 context with previously published molecular data for South American Enantiobuninae,

118 Sclerosomatidae, Phalangiidae, and Caddidae. We examine the congruence between our

119 molecular results against the current and historical species designations based on

120 morphology, including the assignment of females to species based on molecular data.

121 Additional population-level work is presented in an accompanying paper dealing with

122 species delimitation (Fernández et al., submitted). We also analyse our data and comment

123 on the monophyly of the current genera and the validity of historical diagnostic

124 characters.

125 


\section{Materials and methods}

\section{Specimen sampling}

128 Our sampling included 92 fresh specimens, 11 from Australia, 2 from South Africa and

12979 from New Zealand, collected from 2002 to 2014 (Table 1 and Fig. 5). Specimens were

130 collected by hand and preserved in $96 \%$ ethanol and stored at $-80{ }^{\circ} \mathrm{C}$ for long-term

131 preservation of DNA. Sequences from GenBank belonging to the family Caddidae were

132 used to root the trees (Table 1). A specimen of Phalangium opilio, also collected in New

133 Zealand, was used along GenBank sequences from other studies including Phalangiidae,

134 Sclerosomatidae, Vibone, Thrasychirus, Hesperopilio, Ballara and other Neopilionidae to

135 test the monophyly of Enantiobuninae, Neopilionidae, and Monoscutidae as presently

136 defined (Giribet, Vogt et al. 2010; Hedin, Tsurusaki et al. 2012; Groh and Giribet 2014).

137 Most specimens were collected from the vegetation, walking about, or from the underside

138 of fallen logs and rocks, and were most abundant during night time. Specimens were

139 deposited at the Museum of Comparative Zoology, Harvard University, Cambridge,

140 Massachusetts, USA (MCZ) the Zoological Museum, Natural History Museum of

141 Denmark (NHMD), and the Museum of New Zealand/Te Papa Tongarewa, Wellington,

142 New Zealand (TPT). All DNA isolates from new material were deposited at the MCZ

143 except for Pantopsalis snarensis, which was deposited at TPT.

145 Molecular sequences

146 Total genomic DNA was isolated from one leg from each specimen with the DNeasy®

147 Tissue Kit (QIAGEN, Valencia, California, USA). We sequenced the a 540 fragment of

148 the $18 \mathrm{~S}$ rRNA gene and a $2.2 \mathrm{~kb}$ fragment of $28 \mathrm{~S}$ rRNA nuclear ribosomal genes, and a 
$149745 \mathrm{bp}$ fragment of the protein-encoding mitochondrial gene cytochrome $c$ oxidase

150 subunit I (COI), all which have been recently used for the estimation of phylogenetic

151 relationships within arthropods, particularly the order Opiliones (Edgecombe, Wilson et

152 al. 2000; Giribet, Edgecombe et al. 2001; Prendini, Crowe et al. 2003; Boyer and Giribet

153 2004; Prendini, Weygoldt et al. 2005; Boyer, Baker et al. 2007; Boyer, Clouse et al.

154 2007; Boyer and Giribet 2007; Sharma and Giribet 2009; Murienne, Edgecombe et al.

155 2011)

156 COI was PCR amplified using the primer pair LCO1490 (Folmer, Black et al.

157 1994) and HCOoutout (Prendini, Weygoldt et al. 2005; Schwendinger and Giribet 2005);

158 18S rRNA using primer sets 1F-4R, 4F-18Sbi, and 18Sa2.0-9R (Giribet, Carranza et al.

159 1996; Whiting, Carpenter et al. 1997) and 28S rRNA with primer sets 28S1F-28Srd4b,

160 28Sa-28sb, and 28Srd4.8a-28Srd7b1 (Park and Ó Foighil 2000; Schwendinger and

161 Giribet 2005; Edgecombe and Giribet 2006). PCR products were visualized in 1\%

162 agarose gel electrophoresis, and purified PCR products with the Millipore MultiScreen

$163 \mathrm{PCR} \mu 96$ filter plate system (Millipore, Waltham, MA). For the sequencing reaction we

164 used the BigDye (Applied Biosystems) and cleaned unincorporated primers and dye with

165 Performa DTR Plates (Edge Biosystems; Gaithersburg, MD). We analysed the labelled

166 fragments with an ABI Prism 3730xl Genetic Analyzer (Applied Biosystems), and edited

167 the resulting .ab1 files using SEQUENCHER 4.7 (Gene Codes Corporation 2007; Ann

168 Arbor, MI). We visually inspected all fragments, sequenced using both primers, to

169 ascertain ambiguous base calls or detect possible contamination. All sequences were

170 deposited in GenBank and accession numbers are provided (Table 1). 
172 Phylogenetic analysis

173 All file format manipulations were performed with Mesquite (Maddison and Maddison

174 2010), and sequence alignments for the maximum likelihood analyses were performed

175 with MUSCLE 3.7 (Edgar 2004). For the maximum likelihood estimation of

176 phylogenetic trees we used RAxML (Stamatakis 2006). jModeltest (Posada 2009) was

177 used to select the best-fit evolutionary model under the Akaike information criterion

178 (AIC) (Akaike 1974): GTR + gamma + invariant sites (Yang 1993). Bootstrap support

179 values were calculated from 100 replicates. The direct optimization method (Wheeler

180 1996; Wheeler, Aagesen et al. 2006) as implemented in POY (Wheeler, Lucaroni et al.

181 2014) was used to evaluate trees under the parsimony criterion. The data were partitioned

182 in a priori segments to avoid clustering of sequences with missing ends. One of the

183 equally-parsimonious trees was selected for measuring nodal support, and jackknife

184 support was calculated by resampling the data 100 times with a 0.36 probability of

185 deletion. Consensus trees were calculated with the Consense program in the PHYLIP

186 package (Felsenstein 1989), and trees reorganized in FigTree (Rambaut 2011).

189 Results and discussion

190 Monophyly of Neopilionidae

191 Our results from both the parsimony and the maximum likelihood criteria (Figs. 6, 7)

192 reject Neopilionidae sensu Šilhavý (1970) and sensu Taylor (Taylor 2011; Taylor 2013b),

193 as it includes the two representatives of the genus Hesperopilio Shear, 1996, formerly in

194 Caddidae (Shear 1996) but recently transferred to Phalangioidea (Groh and Giribet 2014). 
195 These results are relevant as they are the first molecular evidence of the paraphyly of

196 Neopilionidae in the long and complicated history of the family.

197 The family Neopilionidae (sensu Ballarinae + Enantiobuninae + Neopilioninae,

198 see Fig. 1) has had an interesting, if also very unstable history. In 1931, Lawrence erected

199 the subfamily Neopilioninae Lawrence, 1931 for a new South African species, Neopilio

200 australis Lawrence, 1931. Also in 1931, Mello-Leitão described the subfamily

201 Enantiobuninae Mello-Leitão, 1931 using material from South America, but later in that

202 same year he synonymized it with Neopilioninae (Mello-Leitão 1931). In 1948 Forster

203 created the subfamily Monoscutinae Forster, 1948 for two New Zealand species:

204 Acihasta salebrosa Forster, 1948 and Monoscutum titirangiensis Forster, 1948. Forster

205 characterized this New Zealander group of Eupnoi by not having dorsal opisthosomal

206 segmentation (Forster 1948b). A year later, Forster erected Megalopsalinae Forster, 1949

207 to accommodate Megalopsalis Roewer, 1923, Spinicrus Forster, 1949 and Nodala

208 Forster, 1949, all from Australia (Forster 1949a). Kauri (1961) described the genus

209 Vibone Kauri, 1961 and elevated Neopilioninae to family, as Neopilionidae Kauri, 1961.

210 By this time, even as the classification of the family matured, in 1962 Forster still

211 considered the New Zealand genera Megalopsalis and Pantopsalis part of Phalangiinae

212 (Forster 1962a), unrelated to his other material designated as Monoscutinae, and even

213 still in 1964 still listed Pantopsalis under Phalangiidae (Forster 1964a). Šilhavý (1970)

214 provided a historical account of Neopilionidae and divided the family into geographical

215 groups, with Neopilioninae for the South African genera, with a reduced palpal tarsal

216 claw, Megalopsalinae for the Australian and New Zealand genera (although not 
217 mentioning Acihasta Forster, 1948), recognizing variation in the palpal tarsal claw, and

218 Enantiobuninae for the South American species in the genus Thrasychirus Simon, 1884.

220 Work continued in 1970 with the addition of Megalopsalidinae (Megalopsalinae [sic]

221 which then included the genus Monoscutum Forster, 1948) (Martens 1976a), into an

222 sextended Neopilionidae by Šilhavý (1970) (Fig. 1). Later Martens (1976b) raised

223 Megalopsalinae to family level and corrected the name to Megalopsalididae. Two

224 decades later, Hunt and Cokendolpher (1991a) erected the taxon Ballarrinae for Vibone

225 Kauri, 1961 (from South Africa) with four new genera: Ballarra Hunt \& Cokendolpher,

226 1991, Plesioballarra Hunt \& Cokendolpher, 1991 and Arrallaba Hunt \& Cokendolpher,

2271991 (southern Australia), and Americovibone Hunt \& Cokendolpher, 1991 (southern

228 South America). However, their cladistic morphological analysis did not support

229 monophyly of Neopilionidae (Fig. 1). Monoscutinae and Megalopsalidinae, however,

230 continued to be recognized by subsequent authors, e.g., Hunt (1990b), Hunt and

231 Cokendolpher (1991a), and Taylor (2004b), although the monophyly of Monoscutidae

232 was still based on a single character, the presence of paired lateral bristle groups on the

233 penis at the shaft or glans articulation (Hunt and Cokendolpher 1991a) (of importance is

234 to note that Monoscutidae has previously been incorrectly referred to as

235 Megalopsalididae, before Crawford (1992b) pointed out that the subfamily Monoscutinae

236 had priority over Megalopsalidinae).

237 Up to this point, Monoscutidae thus contained two distinctive subfamilies,

238 Monoscutinae and Megalopsalidinae, Monoscutinae containing three monotypic genera

239 (1) Monoscutum Forster, 1948, (2) Acihasta Forster, 1948, and (3) Templar Taylor, 2008, 
240 the latter only recently added (Taylor 2008a), and an undescribed species of an uncertain

241 genus from New South Wales, Australia (Hunt 1990b; Hunt and Cokendolpher 1991a).

242 Megalopsalidinae contained three genera: (1) Megalopsalis (13 spp.), (2) Pantopsalis (11

243 spp.), and (3) Spinicrus (8 spp.) (see Taylor, 2004 for a checklist). In 2011 Taylor

244 synonymised Monoscutidae with Neopilionidae using results from a morphological

245 cladistic analysis that showed Monoscutidae to be nested within Neopilionidae (Neopilio

$246+($ Ballara + Monoscutidae) $)$, and which positioned the Chilean Thrasychirus Simon,

2471884 (Neopilionidae: Enantiobuninae) within Monoscutidae, which, as we have

248 discussed, was up to then a group otherwise wholly constrained within New Zealand and

249 Australia (Taylor 2011). This conclusion, based on a few morphological characters, was

250 not supported in the unweighted parsimony tree, and thus awaited the inclusion of more

251 samples from Neopilionidae and the addition to the analysis of more characters,

252 molecular and morphological (see Taylor 2013 for another analysis with monophyly of

253 Neopilionidae). However, regardless of the sister vs. nested relationship between

254 Neopilionidae and Monoscutidae, the inclusion of Thrasychirus within Monoscutidae

255 changed the name of the family or subfamily, wherever a final taxonomic revision lands

256 the ranking, to Enantiobuninae, which has priority (Taylor 2011; Taylor 2013a).

257 This new Enantiobuninae (sensu Thrasychiroides + Thrasychirus + former

258 Monoscutidae, see Fig. 1), lacks consistent synapomorphies and diagnostic characters,

259 and in the field they are normally identified as being the only group of Opiliones within

260 New Zealand and Australia with long legs, save for the synanthropic species Phalangium

261 opilio (Phalangiidae) and Nelima doriae (Sclerosomatidae) and the endemic but small

262 Acropsopilio neozelandiae (Acropsopilionidae) (Forster 1948a; Taylor 2011). 
White (1849a) described the first member of what was to become the Eupnoi of

264 New Zealand and Australia, Phalangium listeri from New Zealand, which would later be

265 transferred to the genus Pantopsalis as its type species (Simon 1879a). The holotype,

266 however, has been reported as lost (Taylor 2004a; Taylor 2013a), and the original

267 description had no specific locality information as to where within New Zealand the

268 specimen was collected, and lacked diagnostic characters (White 1849a; Simon 1879a;

269 Taylor 2004a). Taylor (2004) first declared the species a nomen dubium and later

270 reinstated it (Taylor 2013a) after examination of associated material purportedly used by

271 Simon in the original description of the species. Neotypes were then assigned, however,

272 while reporting variation within the specimen lot on the morphology of the enlarged

273 chelicerae of the males, quite possibly the most important character for species

274 identification in the family. Colenso (1882b) later described Phalangium cheliferoides,

275 which was later transferred to Pantopsalis (Nicholls, Sirvid et al. 2000). Taylor (2004),

276 however, reported a deteriorated type and no other specimens with good characters to

277 distinguish it from other species, and declared it a nomen dubium. Although he later

278 reestablished the species, the diagnostic characters remained unclear: e.g., although the

279 presence of a medial stripe on the opisthosoma was presented as diagnostic, this character

280 state is shared by other related species, and is missing in one of the specimens assigned to

281 the species in the same study (Taylor 2013a).

282 Sørensen (1886) described the first Australian Eupnoi, Macropsalis serritarsus,

283 which was later changed to Megalopsalis because Macropsalis was pre-occupied by a

284 bird genus (Roewer 1923). The description of Megalopsalis included a first attempt at

285 characters for inter-generic diagnosis: (1) spines on the ocularium, (2) abdomen shorter 
286 than cephalothorax, (3) tibia and patella of palpus of unequal length in Pantopsalis, (4)

287 tibia II with pseudoarticulations, and (5) a ramous bifurcation in the patella of the palpus

288 in Megalopsalis. All of these, except for the patella of the palpus, were considered

289 plesiomorphic states by later authors (Taylor 2004a; Taylor and Hunt 2009) (but see

290 below for further discussion on the cladistic value of the patella). Pocock (1902b) added

291 Macropsalis hoggi Pocock, 1902, Pantopsalis albipalpis Pocock, 1902, P. nigripalpis

292 Pocock, 1902, and P. nigripalpis spiculosa Pocock, 1902, and later (1903a) P. coronata

293 Pocock, 1903, Pantopsalis trippi Pocock, 1903 and Pantopsalis jenningsi Pocock, 1903,

294 followed by Hogg (1909) with Macropsalis chiltoni Hogg, 1909, and Pantopsalis

295 tasmanica Hogg, 1909. Roewer (1911) attempted a first taxonomic grouping with other

296 long-legged Opiliones by including Megalopsalis and Pantopsalis within the African and

297 Holarctic Phalangiinae, a classification which was quickly discarded by subsequent

298 authors. Species descriptions continued in that century with Hogg (1920) adding

299 Pantopsalis wattsi Hogg, 1920, P. pococki Hogg, 1920, P. grayi Hogg, 1920 and P. halli

300 Hogg, 1920. Roewer (1923) added Pantopsalis continentalis Roewer, 1923, and later

301 Macropsalis (Megalopsalis) fabulosa Grimmett \& Phillips, 1932 was also described.

302 Forster (1944b) made the first attempt at a complete revision of the New Zealand and

303 Australian Eupnoi genera, adding several species to Megalopsalis without apparently

304 looking into the many species already described in Pantopsalis. Despite expressing

305 doubts about the cladistic value of the only remaining diagnostic character separating the

306 Megalopsalis from Pantopsalis, the ramous patella of the palp, Forster added

307 Megalopsalis chiltoni Forster, 1944, M. chiltoni nigra Forster, 1944, M. inconstans

308 Forster, 1944, M. tumida Forster, 1944, M. triascuta Forster, 1944, M. luna Forster, 1944, 
309 M. marplesi Forster, 1944, and M. grimmetti Forster, 1944. Forster also later made the

310 first conjectures about phylogeographic relationships among the described species, and

311 noted the probable close relationship between the New Zealand and Australia opilionid

312 fauna (Forster 1947). A year later, Forster (1948c) also established Monoscutinae

313 (although joined by plesiomorphies), and added two monotypic genera with Acihasta

314 salebrosa Forster, 1948 and Monoscutum titirangiensis Forster, 1948. In the first

315 comprehensive treatment of the Australian monoscutids, Forster (1949b) established

316 Megalopsalinae (as per our historical overview above, later corrected for spelling and

317 upgraded to the family level Megalopsalididae (Martens 1976a).) However, from a

318 family status, Megalopsalididae was later downgraded again under Monoscutidae (Hunt

319 1990a; Hunt and Cokendolpher 1991b; Crawford 1992a). Forster subsequently raised the

320 genus Spinicrus Forster, 1949 to distinguish the Australian and New Zealand species,

321 adding S. camellus Forster, 1949, S. stewarti Forster, 1949, and transferring from

322 Pantopsalis both S. tasmanica (Hogg 1909) and just based on the published description,

323 S. continentalis (Rower 1923). Kauri (1954) and later Hickman (1957) added S. minumus

324 Kauri, 1954, S. porongorupensis Kauri, 1954, S. thrypticum Hickman, 1957, and S.

325 nigricans Hickman, 1957. Back in New Zealand, and again despite doubting the

326 diagnostic value of the palpal patellar character on which the whole classification rested,

327 Forster added Pantopsalis johnsi Forster, 1964, P. mila Forster, 1964, P. distincta

328 Forster, 1964, P. snaresensis Forster, 1964 and P. rennelli Forster, 1964. In one of the

329 last chapters or the taxonomic history of the group, Taylor revised Pantopsalis, adding $P$.

330 phocator Taylor, 2004, synonymizing $P$. nigripalpis and $P$. jenningsi (with $P$. albipalpis),

331 P. trippi (with P. coronata), P. mila (with P. johnsi), and making the following generic 
332 transfers: Pantopsalis wattsi, P. grayi, P. distincta to Megalopsalis, and Megalopsalis

333 luna to Pantopsalis. In 2008 Taylor (2008b) added Megalopsalis linaei Taylor, 2008,

334 which he later (Taylor 2011) transferred to a new genus, Tercentenarium Taylor, 2011.

335 Taylor (2009) then went on to erect the new genus Neopantopsalis Taylor, 2009, in an

336 attempt to reorganize Spinicrus from geography-based to cladistics, using the following

337 characters for Neopantopsalis: raised bumps in the dorsal prosomal plate (only in 'major'

338 males), the presence of hyperthophied spines on leg I ('major' males again), and oblong

339 dorsoventrally flattened glans of the penis; kept Megalopsalis defined with the character

340 of the patellar ramification, and added for Spinicrus the characters of dorsal margin of the

341 prosoma horizontal rather than sloping, and flattened glans of the penis. Taylor (2009)

342 also added Neopantopsalis quasimodo Taylor, 2009, N. pentheter Taylor, 2009, N. psile

343 Taylor, 2009 and $N$. thaumatopoios Taylor, 2009, while noting that probably none of the

344 Australian genera of Monosctutidae, as listed then, formed monophyletic groups. The

345 same reorganization was done for the New Zealand Megalopsalis, and all species in the

346 country where either declared nomina dubia, synonymized, or transferred to a new genus,

347 Forsteropsalis Taylor, 2011, to which one species was subsequently added,

348 Forsteropsalis pureroa Taylor, 2013 (Taylor 2011; Taylor 2013a). Left standing were

349 thus: Forsteropsalis chiltoni (Hogg, 1910), F. distincta (Forster 1964), F. fabulosa

350 (Phillipps \& Grimmett, 1932), F. grayi (Hogg, 1920), F. grimmetti (Forster, 1944), F.

351 inconstans (Forster, 1944), F. marplesi (Forster, 1944), F. nigra (Forster, 1944), F. wattsi

352 (Hogg, 1920) and F. pureroa Taylor, 2013; with a new Australian species added to

353 Megalopsalis based on the patellar character: M. epizephyros Taylor, 2011, M. eremiotis

354 Taylor, 2011, M. leptekes Taylor, 2011, and M. pilliga Taylor, 2011. 
355 Our results, thus, find no evidence to support either Monoscutidae sensu

356 Crawford (1992b) or sensu Cokendolpher and Taylor (2007b) (Fig. 1). They also support

357 the idea that Hesperopilio (Australia and Chile, formerly in Caddidae (Groh 2014)) is

358 closely related to the now-entirely South American Enantiobuninae, here represented by

359 Thrasychirus gulosus (Hedin, Tsurusaki et al. 2012). Although this represents the first

360 large analysis of Neopilionidae and other related taxa using molecular data (see also Groh

$361 \&$ Giribet, 2014), we refrain from proposing any taxonomic changes until a denser

362 sampling, especially of the New Zealand genera Acihasta, Monoscutum, and

363 Australiscutum, additional Australian fauna, the South American Thrasychirus and most

364 important, the South African Neopilio are included in the analyses. However, it is

365 comforting to see another large Opiliones clade with deep biogeographic structure,

366 including a distribution similar to those of the families Pettalidae and Triaenonychidae

367 (Giribet \& Kury, 2007), and thus we centre our phylogenetic discussion on the New

368 Zealand species of Enantiobuninae.

369 Taylor's (2011) morphological cladistic analysis found that none of the then-

370 "neopilionid" genera formed monophyletic groups (although, it must be noted, they did

371 form a clade under the weighted analysis) and based on these results, he synonymised

372 Monoscutidae with Neopilionidae. Our sampling does not allow for a complete resolution

373 of this long-standing controversy (e.g., Šilhavý 1970; Hunt and Cokendolpher 1991a;

374 Taylor 2011), as many key genera were not sampled: e.g. Neopilio, some members of

375 Monoscutinae, e.g. Acihata, Monoscutum, or Australiscutum, nor some key genera from

376 Megalopsalidinae: e.g. Tercentenarium. However, our results do show that our clade of

377 Australian/New Zealand species does not include the South African Vibone, originally 
378 described in Neopilionidae (Kauri 1961). Although Hunt and Cokendolpher (1991a)

379 transferred Vibone from Neopilioninae to their new subfamily Ballarrinae, our analyses

380 reject this relationship, as Ballarra groups with the Australasian clade that includes

381 Pantopsalis, Forsteropsalis, Spinicrus, Mangatangi, etc., and does not group with its

382 Neopilionidae clade (Hunt and Cokendolpher 1991a; their figure 4A) or with Ballarrinae

383 (their figure 4B). Our results therefore agree with Taylor's (2011) unweighted

384 morphological cladistic analysis, in that it separates Ballarra from the other

385 Neopilionidae (although Vibone was not sampled in that study).

387 Broader relationships among the New Zealand + Australia native eupnoids

388 The internal relationships within the Megalopsalididae are not fully supported in our

389 analysis, although Ballarra (Ballarrinae) shows as the sister group of the remaining

390 genera. Within the New Zealand + Australian native eupnoids, the first division is

391 between the clade with pectinate palpal claws and a clade with smooth palpal claws (Fig.

392 8). The pectinate-claw divides is divided into the New Zealand Mangatangi and the

393 Australian species (probably Megalopsalis); the smooth-claw finds support for a clade of

394 Forsteropsalis, a clade of Pantopsalis and a clade that includes Forsteropsalis pureora,

395 F. wattsi and Megalopsalis turneri, but neither this clade nor its relationship to the other

396 clades is well resolved. Additionally, two other undescribed species, here represented by

397 specimens MCZ 29229 and MCZ 29239 have an unsupported position.

399 The Megalopsalidinae of New Zealand: a taxonomic overview of Pantopsalis and $400 \quad$ Forsteropsalis 
401 The distinction among the genera within the former Monoscutidae has been problematic

402 since the description of each genus (Cokendolpher and Taylor 2007a). For example,

403 when Sørensen (1886) described Macropsalis (now Megalopsalis), he used as diagnostic

404 characters the spines on the ocularium of Megalopsalis vs. smooth in Pantopsalis, but

405 since then, many species that now belong in Megalopsalis have been described with a

406 smooth ocularium, while some Pantopsalis continue to be described with spines (Taylor

407 2004a), and in any case, the character might be variable within species. Another

408 character, that of the opisthosoma being longer than prosoma, has the problem that the

409 opisthosoma is soft and prone to deformation during preservation (Taylor 2004a) and in

410 our observation of freshly collected material from type localities, can vary between molts.

411 The difference in size between the patella and the tibia in Pantopsalis, Sørensen's (1886)

412 "palporum partibus patellari et tibiali sibi longitudine sub aequalibus", is also of

413 doubtful validity since both characters can vary within species (Hickman 1957, see

414 Taylor, 2004). The last remaining characters are the presence of a spiny process in the

415 patella of the palp (between Pantopsalis vs. Forsteropsalis and between Spinicrus +

416 Neopantopsalis and Megalopsalis), the number of brushes in the penis between

417 Forsteropsalis and Pantopsalis, the bowing of the cheliceral claw between Pantopsalis

418 vs. Forsteropsalis, and a 'triangular dorsolateral keel on the glans, with the apex of the

419 triangle at the distal end of the glans' (Taylor 2011), also between Forsteropsalis and

420 Pantopsalis. All of these characters are of suspect validity: for example, from Taylor's

421 (2004) illustrations the scoring of abundance of penis bristles seems to be subjective. The

422 palpal patellar structure, also described as a branch (Sørensen’s (1886) "parte patellari

423 non ramosa"), splitting, spur, process (Forster 1944b), or apophysis (Taylor 2004a; 
424 Taylor and Hunt 2009), has been especially problematic, since it has been used as the

425 sole basis in the erection of new genera and in the transfer species between genera. For

426 example, using the patellar process as a character, Taylor (2004) transferred Forster's

427 (1964b) Pantopsalis distincta to Megalopsalis distincta even though the purported female

428 of the species does not have a patellar process, and the purported male only has a small,

429 pointed one. In his key, Forster (1944b) used the apophysis to distinguish among the two

430 genera, but then used this character to assign a female specimen of what otherwise

431 seemed like a typical Pantopsalis female to Megalosalis luna (Taylor 2011). Two

432 decades later, Forster again described a new species, Pantopsalis distincta, and included

433 in the description a female with a "well developed process on the prodistal surface of the

434 patella of the palp" (Forster 1964b), the exact then-synapomorphy for the sympatric

435 Megalopsalis (now Forsteropsalis for the New Zealand species). Taylor (2004)

436 continued to use this character throughout his revision of Pantopsalis, making

437 adjustments as to its shape to assign specimens with a patellar process to Pantopsalis.

438 Surprisingly, in Taylor's (2011) own morphology-based cladistic analysis, the patellar

439 process comes as a plesiomorphy. Forster himself had also noted that it might vary within

440 molts of the same individual (Forster 1964b). The distinctive shape of the keel of the

441 glans, the last character state supporting Pantopsalis together, was reported as absent in

442 the resurrection of Pantopsalis cheliferoides (Taylor 2013a).

443 The sequence similarity and subsequent clustering of males and females into well-

444 supported clades confirms a wide range of morphological disparity among species,

445 particularly in the shape, coloration, and size of the male chelicerae, and the presence of

446 sexual dimorphism (Figs. 6, 7) is consistent with a reduced number of species for 
447 Pantopsalis and Forsteropsalis. For these New Zealand species, identifications were

448 made following Taylor's (2004a; Taylor and Hunt 2009; 2011; 2013a) recent revisions of

449 Pantopsalis, Megalopsalis (now Forsteropsalis for the New Zealand species), and

450 Neopantopsalis, as well as the original descriptions. This reduced number of species, in

451 the context of our extensive sampling within New Zealand (Fig. 5), and the fact that most

452 clades included at least one male, suggests that the same approach could lead to a reduced

453 number of species also for the Australian genera of Spinicrus, Megalopsalis, and

454 Neopantopsalis.

455

456 Mangatangi

457 The genus Mangatangi was recently described by Taylor (2013a) based on a male and a

458 female specimens from Mangatangi, Hunua Ra., and a male from Cuvier Is. From this

459 genus, we collected a male in Te Urewera N.P. The genus is easily identified by the

460 pectinate pedipalpal tarsal claw, a character shared with the Australian species of

461 Neopilionidae (Taylor 2004a) (Fig. 8). All the specimens belonging to this genus $(\mathrm{n}=5)$

462 clustered together in a clade. One specimen (MCZ 29239) was identified as Mangatangi

463 parvum, while the other ones could not be identified at the species level based on the

464 available literature. Our specimen from Te Urewera clusters with other specimens from

465 Queen Charlotte Sound and Kaikoura (South Island), although they probably constitute

466 more than one species. Interestingly, in our phylogenetic trees (Figs. 6, 7), Mangatangi

467 forms a clade with the Australian species albeit with low bootstrap support, instead of the

468 New Zealand species, which confirms the importance of the pectinate pediplapal tarsal 
469 claw in the higher systematics of the group.

470

471 The Forsteropsalis pureora, F. wattsi, and M. turneri clade.

472 This clade includes species originally described as Pantopsalis (P. wattsi Hogg, 1920),

473 Forsteropsalis (F. pureora Taylor, 2013) and Megalopsalis (M. turneri Marples, 1944),

474 but its relationship to the other Pantopsalis or Forsteropsalis remains unsupported.

475 Forsteropsalis pureora Taylor, 2013 (Note: The species is referred to as F. pureroa in the

476 abstract and figure captions of the original description) was described by Taylor (2013a)

477 based on a single male specimen from Waipapa Reserve, Pureora, which matches our

478 specimens from Te Urewera National Park (MCZ 29240), but this species also closely

479 matches the description of another North Island species, Forsteropsalis inconstans

480 (Forster 1944b), a species with a problematic history that starts with an original

481 description that included specimens from three different species (Forster 1944b; Taylor

482 2011), and a striking similarity to Forsteropsalis nigra (Forster 1944) except for a few

483 small red markings on the propeltidium (Taylor 2011). Forsteropsalis inconstans also has

484 the same coloration pattern (the "white" markings in the preserved animals of Forster and

485 Taylor are orange in living specimens), from which Taylor distinguished in "not having

486 the posterior part of the propeltidium and the mesopeltidium heavily denticulate", while

487 also mentioning how $F$. pureora can be confused with $F$. distincta, $F$. chiltoni, $F$.

488 marplesi and F. wattsi. 
In our analyses, the $F$. pureora specimens appear as the sister group to what we

490 identified as F. wattsi (Hogg 1920), another North Island species with the "wide

491 horseshoe belt of bright cream-colour", which was described based on a single specimen

492 from Hawera. Our specimens from Mount Stokes and Hori Bay form a clade, although

493 some specimens match the description of Hogg (1920), including how the horseshoe belt

494 of bright cream-colour has "intervals into the lighter colour".

495 All of the cave-dwelling specimens collected formed a third cluster of specimens

496 members of this larger clade, despite some being collected from opposite sides of the

497 South Island. The majority of the specimens were, however, collected ca. $100 \mathrm{~km}$ from

498 the type locality of the South Island endemic Megalopsalis turneri Marples, 1944, and

499 formed a clade with a male that matches the original description of M. turneri, based on a

500 single dried specimen collected near Lake Manapouri. This species was considered by

501 Taylor (2011) as a probable member of Forsteropsalis, but not transferred. It also seems

502 that this is the species discussed in Meyer-Rochow's (1988) work (see discussion below

503 on Forsteropsalis tumida reported from the Waitomo Cave system), since Meyer-

504 Rochow's specimens were adapted to living in caves with bioluminescent fungus gnats,

505 and while repelled by sunlight are nevertheless particularly sensitive to the

506 bioluminescent spectra emitted by the insects in these caves. All of the specimens

507 included in this clade from the analysis were collected near bioluminescent fungus gnats.

508 Pantopsalis: The listeri group

509 The remaining samples of Pantopsalis constitute a clade including specimens from

510 Southland to Te Urewera N.P. This clade includes dark species (black carapace) with a 
511 brown to reddish pigmented pedipalpal femur (from half to most of its length), not pink,

512 the rest of the pediplap being white. It also includes specimens with black opisthosomas

513 or with different degrees of a white-silver strip in the intercalary membrane of the

514 opisthosomal tergites.

515 Our analyses identify two main clades of specimens similar to P. listeri (White,

516 1849). Taylor (2013b) provides a redescription and a discussion of this species, based on

517 examination of a neotype from the MNHN, Paris, and uses Simon (1879b) concept of the

518 species, adding the following to the description "Dorsum of opisthosoma with pale

519 silvery, narrow, transverse stripes on posterior margins of segments", illustrated in a live

520 specimen photographed by Simon Pollard (of unspecified precedence). We have

521 observed such transverse stripes with a large degree of variation, from very broad in

522 specimens from Kahurangi N.P. and Arthur's Pass N.P. to less conspicuous in Westland

523 Tai Puitini N.P. and Te Urewera N.P., or totally absent in Mount Aspiring N.P. (see

524 Fernández et al., submitted). Taylor (2013b) also illustrated P. cheliferoides (Colenso

525 1882a), the only Pantopsalis reported from the North Island, an animal similar in

526 morphology to some of the "listeri" morphotypes with swollen chelicera, similar to some

527 of our specimens from Kahurangi N.P. and Mount Aspiring N.P.. Many of these localities

528 find astonishing disparity in cheliceral size and shape, or in the banding pattern of the

529 opisthosoma, despite belonging to the same clade. Our two clades of "listeri" include (1)

530 specimens from the North and South Islands: Te Urewera N.P., Wellington, Kahurangi

531 N.P., Arthur's Pass N.P., and a female from Waimate, spanning almost the whole

532 country, which we assign to $P$. cheliferoides following Taylor (2013b); and (2) specimens

533 from Mt. Aspiring N.P., and Westland Tai Puitini N.P., of much more restricted 
534 geographical distribution, with smoother ocularium, which we assign to P. listeri. The

535 original description of $P$. listeri is inaccurate, and no types or type locality exist, although

536 the species was probably based on specimens from the North Island. However, Simon

537 (1879b) designated a neotype from Westland-Tai Poutini, and we follow Taylor (2013b)

538 with respect to the stability of the type of the genus.

$539 \quad$ White (1849b) succinctly described Phalangium listeri White, 1849, with New

540 Zealand as its type locality, and Simon (1879b) redescribed the species. Taylor (2013b)

541 interpreted that a possible locality for the species was the Bay of Islands, in the North

542 Island, but designated as a neotype a MNHN specimen, presumably examined by Simon,

543 from 'Ile du Milieu, Filhol', probably referring to its collector, Henri Filhol, who was a

544 member of the 1874 French Transit of Venus expedition to Campbell Island. On his way

545 back from Campbell Island, Filhol made stops at Stewart Island, Christchurch,

546 Wellington and Auckland, and could have picked up the P. listeri specimens during his

547 Christchurch stop. 'Ile de Milieu' is the French name for the South Island. Taylor (2013b)

548 appealed to the criterion of stability to assign $P$. listeri to the MNHN specimens

549 examined by Simon from Westland, and thus we use the name P. listeri for our restricted

550 clade, including specimens from Westland-Tai Poutini and Mt. Aspiring N.P.

551 Pantopsalis albipalpis Pocock, 1903b is another dark species with the clear palps

552 from the South Island, described based on specimens from near Dunedin (Pocock 1903b),

553 including multiple synonymies, such as Pantopsalis nigripalpis Pocock, 1903b, $P$.

554 nigripalpis spiculosa Pocock, $1903 \mathrm{~b}$ and $P$. jenningsi Pocock, 1903a; all synonymised by

555 Taylor (2004b). It is unlikely that $P$. albipalpis would remain as a valid species. name for

556 the South Island. Taylor (2013b) appealed to the criterion of stability to assign P. listeri 
557 to the MNHN specimens examined by Simon from Westland, and thus we use the name

558 P. listeri for our restricted clade, including specimens from Westland-Tai Poutini and Mt.

559 Aspiring N.P.

560 Pantopsalis albipalpis Pocock, $1903 \mathrm{~b}$ is another dark species with the clear palps

561 from the South Island, described based on specimens from near Dunedin (Pocock 1903b),

562 including multiple synonymies, such as Pantopsalis nigripalpis Pocock, 1903b, $P$.

563 nigripalpis spiculosa Pocock, $1903 \mathrm{~b}$ and P. jenningsi Pocock, 1903a; all synonymised by

564 Taylor (2004b). It is unlikely that $P$. albipalpis would remain as a valid species. While

565 the genetic diversity of $P$. phocator was relatively high, both $P$. cheliferoides and $P$.

566 listeri showed a low percentage of pairwise differences $(0.5 \%)$ and medium to low levels

567 of haplotypic and nucleotidic diversity.

569 A discussion of the distinctions between Forsteropsalis and Pantopsalis

570 Although none of the specimens from the Pantopsalis clades had a large patellar process,

571 it is not clear that this trait can be used as a diagnostic character. In his last published

572 comment on Pantopsalis, Forster (1964b) referred to an unpublished study of the New

573 Zealand species indicating that the patellar process is a secondary sexual character often

574 present in the females but not the males, citing as an example Pantopsalis rennelli, where

575 the males do not have the process but the females do. Furthermore, Forster noted that the

576 patellar process is 'extraordinarily well developed' in early developmental stages but

577 diminishes with every moult. Our data and phylogenetic analyses support this latter view 
578 (Fig. 9). However, most females of Pantopsalis displayed an hourglass-like mark in their

579 backs, while the Forsteropsalis females displayed a box-like mark typical of other

580 Australian and New Zealander eupnoids, such as Spinicrus and Mangatangi (Fig. 10.)

581

582 Forsteropsalis

583 A single male individual from Te Urewera National Park with an unusual palp

584 morphology was collected, MCZ 29239. This species displays the cream-colored

585 prosomal horseshoe, smooth ocularium, but the opisthosoma is brown, with two

586 longitudinal darker bands. Most conspicuous characteristics are the heavily denticulate

587 chelicerae and the elongated palps of uniform brown color, unlike most other species that

588 display shorter palps with the distal segments lightly pigmented. This species was

589 collected together with Mangatangi parvum, Forsteropsalis pureora, and F. Nigra.

$590 \quad$ A member of Forsteropsalis, a single specimen (MCZ 29252) differs from all

591 other members of the clade in having a palp mostly without conspicuous colour patterns,

592 as opposed to its sympatric species $F$. wattsi. It does have "remnants" of the cream-colour

593 horseshoe, but limited to two small marks.

595 Forsteropsalis fabulosa 
596 We found another clade including just a few specimens, which includes a male and a

597 female of Forteropsalis fabulosa (Phillipps and Grimmett, 1932) from Belmont Regional

598 Park, Wellington (the type locality given by Phillipps and Grimmett, 1932 was also

599 Wellington). Forsteropsalis fabulosa is the sister group to a clade that includes 1 female

600 from Kaikoura, and 1 female and 1 small female-looking specimen with enlarged

601 chelicers (probably a male of a species without markerd sexual dimorphism) from

602 Hinewai, in Banks Peninsula. Additional collecting in the northeastern region of the

603 South Island should help clarify these putative species.

605 Forsteropsalis chiltoni

606 Forsteropsalis chiltoni (Hogg, 1910) is the only Forsteropsalis species known from

607 Stewart Island (Taylor, 2011) and very similar to F. marplesi (Forster, 1944). We

608 identified a clade of Stewart Island Forsteropsalis, which is unfortunately only

609 represented by females, a juvenile, and a single male, with female coloration, a large

610 ocularium, and with smooth large chelicerae that does not correspond to the description

611 of F. chiltoni either from Hogg (1910) or the redescription by Taylor (2011). However, a

612 different female specimen from Stewart Island clusters with a series of females from

613 Southland, the Catlins and Banks Peninsula. The sister group to this South Island/Stewart

614 Island clade is a male from the Otago Peninsula, matching the description of $F$. marplesi.

615 We thus suspect that the chiltoni group includes multiple species in the eastern-

616 southeastern part of the South Island. We tentatively call the male from Otago $F$. 
617 marplesi, its sister group including the specimen from Stewart Island F. chiltoni, and the 618 other Stewart Island clade Forsteropsalis n.sp.

620 Forsteropsalis inconstans

621 One of the most widespread species of New Zealand monoscutids is Forsteropsalis

622 inconstans. Geographically, specimens from this clade have been collected in the North

623 Island: Tararua Forest Park, relatively near Feilding, the type locality of the species

624 (Forster, 1944), in two localities near Wellington (Karori Wildlife Sanctuary and

625 Wilton's Bush Nature Walk); and in the South Island: Kahurangi N.P., Paparoa N.P.,

626 Haast, Whakapohai Wildlife Refuge, Arthur's Pass N.P., Westland-Tai Poutini N.P., and

627 Mount Aspiring N.P. This clade includes heavily denticulate specimens, including the

628 recently molted female-colored specimens from Kahurangi N.P.

629 Originally $F$. nigra was described as a subspecies of $F$. chiltoni, which had the red

630 markings on the carapace. Forster (1944a) described Megalopsalis inconstans Forster,

6311944 based on a female specimen. In the same paper he described Megalopsalis chiltoni

632 nigra Forster, 1944, based on two male specimens, a subspecies that was elevated to

633 species by Taylor (2011). Our analyses clearly show that the red markings vary with

634 specimens and thus we consider both names to be co-specific. Since Megalopsalis

635 inconstans was published as a species and M. chiltoni nigra as a subspecies, the former

636 name takes priority. We thus consider Forsteropsalis nigra a junior synonym of

637 Forsteropsalis inconstans (new synonymy). 
638 Forsteropsalis inconstans is the sister group to a species represented by a 639 specimen (MCZ129520) from Roaring Billy Falls, in the Haast Pass in the West Coast of

640 the South Island. The latter specimen + Forsteropsalis inconstans are sister to a female

641 (MCZ 29253) from Mt. Stokes, in the Northernmost part of the South Island.

642

\section{Conclusions}

644 Our study is the first to use a molecular data set to study relationships within the New

645 Zealand Neopilionidae. Although we were not able to fully test the monophyly of the

646 New Zealand neopilionids, our data is consistent with the existence of a monophyletic

647 clade of neopilionids from Australia and New Zealand. Our data largely support the

648 current taxonomic revisions for Pantopsalis and Forsteropsalis, and suggest that a

649 reduced number of species seems warranted. More data are however needed to solve the

650 intrageneric relationships, as well as the relationships between the New Zealand genera

651 and the rest of the Australian species of Neopilionidae.

652 


\section{Figure and table captions}

654 Figure 1. (A) Current phylogenetic hypothesis of the internal relationships within

655 Monoscutidae before Taylor's (2011) placement of Monoscutidae (defined as

656 Megalopsalidinae + Monoscutinae) within the Enantiobuninae. (B) Šilhavý’s (1970)

657 classification of Neopilionidae, in which the general formed clades concordant with

658 geography. (C) Hunt and Cokendolpher's (1991) competing hypotheses, neither of which

659 found monophyly for Neopilionidae.

660

661 Figure 2. Examples of Forsteropsalis: (a) Forsteropsalis fabulosa female specimen, for

662 which species determination was made by its proximity to a male of this species; (b)

663 Forsteropsalis fabulosa male, with the most grossly enlarged chelicers of the genus; (c)

664 Forsteropsalis nigra, characterized by sclerotization of the carapace; and (d)

665 Forsteropsalis inconstans. Photos by Sebastián Vélez (a-b) and Gonzalo Giribet (b-d).

668 Figure 3. Variation of chelicerae among species of Forsteropsalis, Pantopsalis, and

669 Spinicrus. (A) Forsteropsalis fabulosa male; (B) Forsteropsalis fabulosa female; (C)

670 Forsteropsalis turneri male; (D) MCZ129520 male; (E) Forsteropsalis nigra male; (F)

671 Forsteropsalis nigra male; (G) Forsteropsalis nigra female; (H) Forsteropsalis marplesi

672 female; (I) Forsteropsalis wattsi male; (J, K) Pantopsalis chiltoni male; (L) Pantopsalis

673 listeri male Type I; Pantopsalis listeri Type II; (O, P, Q) Spinicrus spp. males from

674 Australia.

675 
676 Figure 4. Morphological variation in dentition, claw length, and curvature of female

677 chelicerae of (A) Forsteropsalis turneri, voucher MCZ129521; (B) Mangatangi parvum,

678 voucher MCZ129565; (C) Pantopsalis phocator, voucher MCZ129586; and

679 Forsteropsalis inconstans, voucher DNA129540.

680

681 Figure 5. Map of New Zealand with sampling points. Each dot represents a unique

682 sampling locality. Some dots were slightly shifted to clarify the illustration, and all exact

683 localities are listed on Table 1. Stars indicate type locality for each particular species.

685 Figure 6. Phylogenetic relationships based on a tree selected under the maximum

686 likelihood criterion, with tree search strategy as implemented in RAxML. Numbers above

687 branches indicate bootstrap support values after 100 replicates. Only bootstrap values

$688>50 \%$ are presented.

689

690 Figure 7. Phylogenetic relationships based on a tree selected under the parsimony

691 criterion, under parameter set 111 for a combined COI $+18 \mathrm{~S}+28 \mathrm{~S}$ dataset, as

692 implemented in POY under a dynamic-homology search strategy. Numbers above

693 branches represent jackknife support fractions, 1000 repetitions with 0.36 resampling

694 probability. Only jackknife fractions $>0.50$ are presented. Squares represent if monophyly

695 was found (black) or not (white) for different indel and transversion:transition cost

696 parameters: left to right 111, 121, 141, 211, and 3221. Parameter set names follow Boyer

697 \& Giribet (2007).

698 
699 Figure 8. Comparison of pedipalpal tarsal claw from representative specimens of

700 Mangatangi, Pantopsalis, and Forsteropsalis. (a) Mangatangi parvum. Note the tooth

701 comb on the claw. (b) Pantopsalis sp. (c) Forsteropsalis turneri. (d) Forsteropsalis

702 wattsi.

703

704 Figure 9. Palpi of representative species of Forsteropsalis, Pantopsalis, and Mangatangi

705 showing the relative length of the tubercule of the patella $(\mathrm{Pa})$, indicated by the arrows.

706 Notice how the size does not correlate with the generic placement of each specimen. (a)

707 Forsteropsalis nigra male. (b) Forsteropsalis nigra female. (c) Forsteropsalis wattsi

708 female. (d) Forsteropsalis chiltoni female. (e) Pantopsalis sp. (f) Pantopsalis sp. (g)

709 Pantopsalis sp. (h) Forsteropsalis turneri female. (I) Forsteropsalis turneri female. (j)

$710 \quad$ Mangatangi sp. female.

711

712 Figure 10. Dorsal view of species of Forsteropsalis, Pantopsalis, Mangatangi, and an

713 unidentified Australian species: (A) MCZ129517 Forsteropsalis marplesi; (B)

714 MCZ129519 Forsteropsalis nigra; (C) MCZ129542 Forsteropsalis wattsi; (D)

715 MCZ129587 Pantopsalis listeri; (E) MCZ136146 Pantopsalis phocator; (F)

716 MCZ129549 Australian sp.; (G) MCZ129518 Mangatangi sp.

717

718 Table 1. Voucher, locality and GenBank accession numbers for the sequenced

719 specimens.

720

721 


\section{Acknowledgements}

723 We are grateful to the dedicated group of graduate and undergraduate students from

724 Velez's lab at Worcester State University, who took many of the photographs and SEM

725 images included in this paper: Hyunjin Chung, Adrianna Shays, and Claire Brooks; and

726 others who helped in the sorting, documentation, and maintenance of the specimen

727 collection at the WSU Biology Department: Page Maryyanek and Kelly Hakala. We are

728 also grateful to the New Zealand Department of Conservation for collecting permissions

729 Record Numbers NMINV 02/9 (2002), and 38002-RES (2014). Jagoba Malumbres

730 Olarte, Ricardo Palma, Phil Sirvid, and Pierre Paquin helped us collecting specimens in

731 New Zealand. Greg Holwell and Chris Taylor provided discussion and guidance about

732 neopilionid ecology and systematics. This work was supported by multiple Museum of

733 Comparative Zoology Putnam Expedition Grants to S.V., G.G. and R.F., research grants

734 from the Worcester State Foundation and the Worcester State Office of Academic Affairs

735 to S.V., and the National Science Foundation under Grants Nos 0236871 and DEB-

7360508789 to G.G. R.F. was supported by a fellowship from Fundación Ramón Areces.

\section{$740 \quad$ Literature cited}

741 Akaike, H. (1974) A new look at the statistical model identification. IEEE Transactions on Automatic Control 19(6), 716-723.

744 Boyer, S.L., Baker, J.M., and Giribet, G. (2007) Deep genetic divergences in Aoraki 745 denticulata (Arachnida, Opiliones, Cyphophthalmi): a widespread 'mite harvestman' 746 defies DNA taxonomy. Molecular Ecology 16(23), 4999-5016. 
748 Boyer, S.L., Clouse, R.M., Benavides, L.R., Sharma, P., Schwendinger, P.J.,

749 Karunarathna, I., and Giribet, G. (2007) Biogeography of the world: a case study from

750 cyphophthalmid Opiliones, a globally distributed group of arachnids. Journal of

751 Biogeography 34(12), 2070-2085.

752

753 Boyer, S.L., and Giribet, G. (2004) Biogeographical relationships of new Zealand

754

755

756

757

758

759

pettalidae (Arachnida, Opiliones). Cladistics 20(6), 587-587.

760

761

Boyer, S.L., and Giribet, G. (2007) A new model Gondwanan taxon: systematics and biogeography of the harvestman family Pettalidae (Arachnida, Opiliones, Cyphophthalmi), with a taxonomic revision of genera from Australia and New Zealand. Cladistics 23(4), 337-361.

762

Cokendolpher, J.C. (2007a) Neopilionidae Lawrence, 1931. In 'Harvestmen: The Biology

763

764

765 of Opiliones.' (Eds. R Pinto-da-Rocha, G Machado and G Giribet) pp. 121-123. (Harvard University Press: Cambridge, MA)

Cokendolpher, J.C. (2007b) Protolophidae Banks, 1893. In 'Harvestmen: the Biology of University Press: Cambridge Massachusetts and London) Biology of Opiliones.' (Eds. R Pinto-da-Rocha, G Machado and G Giribet) pp. 118-121. (Harvard University Press: Cambridge Massachusetts)

Cokendolpher, J.C., and Taylor, C.K. (2007b) Monoscutidae Forster, 1948. In

777 Colenso, W. (1882a) On some newly-discovered New Zealand arachnids. Transactions 778 and Proceedings of the New Zealand Institute 15, 165-173.

780 Colenso, W. (1882b) On some newly-discovered New Zealand arachnids. Transactions 781 and Proceedings of the

782 New Zealand Institute 15, 165-73. 
784 Crawford, R.L. (1992a) Catalogue of the genera and type species of the harvestman

785 superfamily Phalangioidea (Arachnida). Burke Museum Contributions in Anthropology

786 and Natural History 8, 1-60.

788 Crawford, R.L. (1992b) Catalogue of the genera and type species of the harvestmen

789 Superfamily Phalangioidea (Arachnida). Burke Museum Contributions in Anthropology

790 and Natural History 8, 1-60.

791

792

Edgar, R.C. (2004) MUSCLE: a multiple sequence alignment with high accuracy and

high throughput. Nucleic Acids Research 32, 1792-1797.

794

795

796

797

Edgecombe, G.D., and Giribet, G. (2006) A century later - a total evidence re-evaluation of the phylogeny of scutigeromorph centipedes (Myriapoda: Chilopoda). Invertebrate Systematics 20(5), 503-525.

800

Edgecombe, G.D., Wilson, G.D.F., Colgan, D.J., Gray, M.R., and Cassis, G. (2000)

801 Arthropod cladistics: Combined analysis of histone H3 and U2 snRNA sequences and morphology. Cladistics 16(2), 155-203.

Felsenstein, J. (1989) PHYLIP - Phylogeny Inference Package (Version 3.2). Cladistics

804 5, 164-166.

805

806 Folmer, O., Black, M., Hoeh, W., Lutz, R., and Vrijenhoek, R.C. (1994) DNA primers

807 for amplification of mitochondrial cytochrome $c$ oxidase subunit I from diverse metazoan 808 invertebrates. Molecular Marine Biology Biotechnology 3, 294-299.

810 Forster, R.R. (1944a) The genus Megalopsalis Roewer in New Zealand with keys to the 811 New Zealand genera of Opiliones. Records of the Dominion Museum 1, 183-192.

813 Forster, R.R. (1944b) The genus Megalopsalis Roewer in New Zealand with keys to the 814 New Zealand genera of Opiliones. Records of the Dominion Museum 1(1), 183-192.

816 Forster, R.R. The zoogeographical relationships of the New Zealand Opiliones. In 'The

817 New Zealand Science Congress', 1947, pp. 233-235 
819 Forster, R.R. (1948a) A new genus and species of the family Acropsopilionidae

820 (Opiliones) from New Zealand. Transactions of the Royal Society of New Zealand 77(1), 821 139-141.

822

823 Forster, R.R. (1948b) A new sub-family and species of New Zealand Opiliones. Records

Forster, R.R. (1949a) Australian Opiliones. Memoirs of the National Museum, Melbourne

Forster, R.R. (1948c) A new sub-family and species of New Zealand Opiliones. Records of the Auckland Institute and Museum 3, 313-318.

838 Forster, R.R. (1962b) A key to the New Zealand harvestmen. Tuatara: Journal of the 839 Biological Society 10, 129-137.

844 Forster, R.R. (1964b) The araneae and opiliones of the sub-antarctic silands of New 845 Zealand. Pacific Insects Monographs 7, 58-115.

847 Forster, R.R. (1965) Harvestmen of the sub-order Laniatores from New Zealand caves. 848 Records of the Otago Museum 2, 1-18.

850 Forster, R.R., and Forster, L. (1999) 'Spiders of New Zealand and their world-wide kin.' 851 (University of Otago Press: Dunedin, New Zealand) 
856 Giribet, G., Carranza, S., Baguñà, J., Riutort, M., and Ribera, C. (1996) First molecular

857 evidence for the existence of a Tardigrada plus arthropoda clade. Molecular Biology and

858 Evolution 13(1), 76-84.

859

860 Giribet, G., Edgecombe, G.D., and Wheeler, W.C. (2001) Arthropod phylogeny based on

861 eight molecular loci and morphology. Nature 413(6852), 157-161.

862

863 Giribet, G., Edgecombe, G.D., Wheeler, W.C., and Babbitt, C. (2002) Phylogeny and 864 systematic position of Opiliones: A combined analysis of chelicerate relationships using

865 morphological and molecular data. Cladistics-the International Journal of the Willi

866 Hennig Society 18(1), 5-70.

867

868 Giribet, G., and Kury, A.B. (2007) Phylogeny and biogeography. In 'Harvestmen: the 869 Biology of Opiliones.'. (Eds. R Pinto-da-Rocha, G Machado and G Giribet) pp. 62-87.

870 (Harvard University Press: Cambridge, Massachusetts, and London, England)

871

872 Giribet, G., Rambla, M., Carranza, S., Baguna, J., Riutort, M., and Ribera, C. (1999)

873 Phylogeny of the arachnid order Opiliones (Arthropoda) inferred from a combined

874 approach of complete $18 \mathrm{~S}$ and partial 28S ribosomal DNA sequences and morphology.

875 Molecular Phylogenetics and Evolution 11(2), 296-307.

876

877 Giribet, G., Vogt, L., Gonzalez, A.P., Sharma, P., and Kury, A.B. (2010) A multilocus

878 approach to harvestman (Arachnida: Opiliones) phylogeny with emphasis on

879 biogeography and the systematics of Laniatores. Cladistics 26(4), 408-437.

880

881 Giribet, G., and Wheeler, W.C. (1999) The position of arthropods in the animal kingdom:

882 Ecdysozoa, islands, trees, and the "parsimony ratchet". Molecular Phylogenetics and

883 Evolution 13(3), 619-623.

884

885 Groh, S. (2014) Systematics of a small harvestman family, Caddidae (Arachnida,

886 Opiliones). Masters Thesis, Harvard University, Cambridge

887

888 Groh, S., and Giribet, G. (2014) Polyphyly of Caddoidea, reinstatement of the family

889 Acropsopilionidae in Dyspnoi, and a revised classification system of Palpatores

890 (Arachnida, Opiliones). Cladistics(doi:10.1111/cla.12087).

891 
892 Hedin, M., Tsurusaki, N., Macías-Ordóñez, R., and Shultz, J.W. (2012) Molecular

893 systematics of sclerosomatid harvestmen (Opiliones, Phalangioidea, Sclerosomatidae):

894 Geography is better than taxonomy in predicting phylogeny. Molecular Phylogenetics

895 and Evolution 62(1), 224-236.

896

897 Hickman, V.V. (1957) Some Tasmanian harvestmen of the sub-order Palpatores. Papers

898 and Proceedings of the Royal Society of Tasmania 91, 65-79.

899

900 Hogg, H.R. (1909) Some New Zealand and Tasmanian Arachnidae. Transactions and

901 Proceedings of the New Zealand Institute, new series 42(273-283).

902

903 Hogg, H.R. (1920) Some Australian Opiliones. Proceedings of the Zoological Society of

904 London(19201), 31-48, pls 1-3.

905

906 Hunt, G.S. (1990a) Taxonomic value of spiracle microstructure in the Megalopsalididae

907 (Opiliones, Phalangioide) Acta Zoologica Fennica 190, 187-194.

908

909 Hunt, G.S. (1990b) Taxonomic value of spiracle microstructure in the Megalopsalididae

910 (Opiliones, Phalangioidea). Acta Zoologica Fennica 190, 187-194.

911

912 Hunt, G.S., and Cokendolpher, J.C. (1991a) Ballarrinae, a new subfamily of harvestmen

913 from the southern hemisphere (Arachnida, Opiliones, Neopilionidae). Records of the

914 Australian Museum 43, 131-169.

915

916 Hunt, G.S., and Cokendolpher, J.C. (1991b) Ballarrinae, a new subfamily of harvestmen

917 from the Southern Hemisphere. Records of the Australian Museum 43(2), 131-169.

918

919 Kauri, H. (1954) Report from Professor T. Gislén's expedition to Australia in 1951-1952.

920 9. Harvest-spiders from S. W. Australia. Lunds Universitets Arsskrift Ny Fjöld

921 Avdelning 2, 5011, 1-10.

922

923 Kauri, H. (1961) Opiliones. In 'South African animal life. Results of the Lund University

924 Expedition in 1950-1951. Vol. 8.' (Eds. B Hanström, P Brinck and G Rudebeck) pp. 9-

925 197. (Almquist \& Wiksell: Uppsala)

926

927 Kury, A.B. (2013) Classification of Opiliones. In '.' (Museu Nacional/UFRJ) 
929 Lawrence, R.F. (1931) The harvest-spiders (Opiliones) of South Africa. Annals of the

$930 \quad$ South African Museum 29, 341-508.

931

932 Machado, G., Pinto-da-Rocha, R., and Giribet, G. (2007) What are Harvestmen? In 933 'Harvestmen: the Biology of Opiliones.'. (Eds. R Pinto-da-Rocha, G Machado and G 934 Giribet) pp. 1-13. (Harvard University Press: Cambridge, Massachusetts, and London, 935 England)

936

937 Maddison, W.P., and Maddison, D.R. (2010) Mesquite: a modular system for 938 evolutionary analysis. In '.' 2.73 edn.)

939

940 Marples, B.J. (1944) A new species of harvestman of the genus Megalopsalis.

941 Transactions of the Royal Society of New Zealand 734, 313-314.

942

943 Martens, J. (1976a) Genitalmorphologie, System und Phylogenie der (Weberknechte 944 Arachnida: Opiliones). Entomologica Germanica, Zeitschrift für das Gesamtgebiet der 945 wissenschaftlichen Entomologie 3(1-2), 51-68.

946

947 Martens, J. (1976b) Genitalmorphologie, System und Phylogenie der Weberknechte 948 (Arachnida, Opiliones). Entomologica Germanica, Zeitschrift für das Gesamtgebiet der 949 wissenschaftlichen Entomologie 3, 51-68.

950

951 Mello-Leitão, C.F.d. (1931) Notas sobre Arachnideos Argentinos. Annaes da Academia 952 Brasileira de Sciencias 32, 83-97, 2 pls.

953

954 Meyer-Rochow, V.B., and Liddle, A.R. (1988) Structure and function of the eyes of two 955 species or opilionid from New Zealand glow-worm caves (Megalopsalis tumida:

956 Palpatores, and Hendea myersi cavernicoloa: Laniatores). Proceedings of the Royal

957 Society of London Series B-Biological Sciences 233(1272), 293-319.

958

959 Murienne, J., Edgecombe, G., and Giribet, G. (2011) Comparative phylogeography of the 960 centipedes Cryptops pictus and C. niuensis (Chilopoda) in New Caledonia, Fiji and 961 Vanuatu. Organisms Diversity \& Evolution 11(1), 61-74. 
963 Nicholls, D.C., Sirvid, P.J., Pollard, S.D., and Walker, M. (2000) A list of arachnid 964 primary types held in Canter- bury Museum. Records of the Canterbury Museum 14(37965 48).

966

967 Park, J.K., and Ó Foighil, D. (2000) Sphaeriid and corbiculid clams represent separate 968 heterodont bivalve radiations into freshwater environments. Molecular Phylogenetics and 969 Evolution 14, 75-88.

970

971 Pinto-da-Rocha, R., Bragagnolo, C., Marques, F.P.L., and Antunes Junior, M. (2014)

972 Phylogeny of harvestmen family Gonyleptidae inferred from a multilocus approach

973 (Arachnida: Opiliones). Cladistics, 1-21.

974

975 Pocock, R.I. (1902a) A new and annectant type of chilopod. Quarterly Journal of 976 Microscopical Science (new series) 45, 417-448.

977

978 Pocock, R.I. (1902b) On some new Harvest-Spiders of the Order Opiliones from the 979 Southern Continents. Proceedings of the Zoological Society of London, 392-413.

980

981 Pocock, R.I. (1903a) Fifteen new species and two new genera of tropical and southern 982 Opiliones. Annals and Magazine of Natural History 11, 433-450.

983

984 Pocock, R.I. (1903b) On some new harvest-spiders of the order Opiliones from the 985 Southern continents. Proceedings of the Zoological Society of London 1902, 392-413.

986

987 Posada, D. (2009) Selection of Models of DNA Evolution with jMODELTEST. In 988 'Bioinformatics for DNA Sequence Analysis.' (Ed. D Posada) pp. 93-112. (Humana Press 989 Inc: New York)

990

991 Prendini, L., Crowe, T.M., and Wheeler, W.C. (2003) Systematics and biogeography of 992 the family Scorpionidae (Cheliceratea: Scorpiones), with a discussion on phylogenetic 993 methods. Invertebrate Systematics 17(185-259).

994

995 Prendini, L., Weygoldt, P., and Wheeler, W.C. (2005) Systematics of the Damon 996 variegates group of African whip spiders (Chelicerata: Amblypygi): evodence from 997 behaviour, morphology and DNA. Organisms Diversity \& Evolution 5, 203-236. 998 
999 Rambaut, A. (2011) FigTree (Version 1.3.1) [Software] Available from

1000 http://tree.bio.ed.ac.uk/software/figtree/. In '.' 1.3.1 edn.)

1001

1002 Roewer, C.F. (1911) Übersicht der Genera der Subfamilie der Phalangiini der Opiliones

1003 Palpatores nebst Beschreibung einiger neuer Gattungen und Arten. Archiv für

1004 Naturgeschichte part I 77 suppl. 2, 1-106, pls 1-3.

1005

1006 Roewer, C.F. (1923) 'Die Weberknechte der Erde. systematische Bearbeitung der Bisher 1007 Bekannten Opiliones.' (VCH: Jena)

1008

Schwendinger, P.J., and Giribet, G. (2005) The systematics of the south-east Asian genus

1010 Fangensis Rambla (Opiliones : Cyphophthalmi : Stylocellidae). Invertebrate Systematics

1011 19(4), 297-323.

1012

1013 Sharma, P., and Giribet, G. (2009) Sandokanid phylogeny based on eight molecular 1014 markers-The evolution of a southeast Asian endemic family of Laniatores (Arachnida, 1015 Opiliones). Molecular Phylogenetics and Evolution 52(2), 432-447.

1017 Sharma, P., and Giribet, G. (2011) The evolutionary and biogeographic history of the 1018 armoured harvestmen - Laniatores phylogeny based on ten molecular markers, with the 1019 description of two new families of Opiliones (Arachnida). Invertebrate Systematics 1020 25(106-142).

1022 Sharma, P., Prieto, C.E., and Giribet, G. (2011) A new family of Laniatores (Arachnida : 1023 Opiliones) from the Afrotropics. Invertebrate Systematics 25(143-154).

Shear, W.A. (1996) Hesperopilio mainae, a new genus and species of harvestman from Western Australia (Opiliones: Caddidae: Acropsopilioninae). Records of the Western 1031

1032 Shultz, J.W. (1998) Phylogeny of Opiliones (Arachnida): An assessment of the "Cyphopalpatores" concept. Journal of Arachnology 26(3), 257-272. 
1035 Shultz, J.W., and Regier, J.C. (2001) Phylogenetic analysis of Phalangida (Arachnida, 1036 Opiliones) using two nuclear protein-encoding genes supports monophyly of Palpatores. 1037 Journal of Arachnology 29(2), 189-200.

1039 Šilhavý, V. (1970) Nouvelles recherches sur la famille des Neopilionidae Lawrence. Bull. Mus. Hist. nat. Paris, ser. 241 (suppl. 1), 171-175.

1041

1042 Simon, E. (1879a) Descriptions d'Opiliones nouveaux. Annales de la Société 1043 Entomologique de Belgique, 22 Comptes-Rendus, 1xx-1xxv. synonymiques et descriptions d'espèces nouvelles. Annales de la Societé Entomologique de Belgique 22, 183-241.

1049 Sørensen, W. (1886) Opiliones descripsit William Sorensen. In 'Die Arachniden Australiens nach der Natur beschrieben und abgebildet. Vol. 2.' (Eds. L Koch and Ev

Stamatakis, A. (2006) RAxML-VI-HPC: maximum likelihood-based phylogenetic analyses with thousands of taxa and mixed models. Bioinformatics 22(21), 2688-2690.

Taylor, C. (2008a) A new species of Monoscutinae (Arachnida, Opiliones, Monoscutidae) from New Zealand, with a redescription of Monoscutum titirangiense. The Journal of Arachnology 36, 176-179.

Taylor, C. (2013a) Further notes on New Zealand Enantiobuninae (Opiliones,

1064 Taylor, C.K. (2004a) New Zealand harvestmen of the subfamily Megalopsalidinae (Opiliones: Monoscutidae) - the genus Pantopsalis. Tuhinga 15, 53-76.

1067 Taylor, C.K. (2004b) New Zealand harvestmen of the subfamily Megalopsalidinae 1068 (Opiliones: Monoscutidae) -- the genus Pantopsalis. Tuhinga 15, 53-76. 
1070

1071

1072

1073 Taylor, C.K. (2011) Revision of the genus Megalopsalis (Arachnida: Opiliones:

1074 Phalangioidea) in Australia and New Zealand and implications for phalangioid

1075

1076

1077

1078

1079

1080

1081

1082

1083

1084

1085

1086

1087

1088

1089

1090

1091

1092

1093

1094

1095

1096

1097

1098

1099

1100

1101 White, A. (1849b) Descriptions of apparently new species of Aptera from New Zealand.

1102

1103
Taylor, C.K. (2008b) A new species of Monoscutidae (Arachnida, Opiliones) from the wheatbelt of Western Australia. Records of the Western Australia Museum 24, 375-380.
Taylor, C.K. (2013b) Further revision of the genus Megalopsalis (Opiliones, Neopilionidae), with the description of seven new species. ZooKeys 328, 59-117.

Taylor, C.K. (2013c) Further revision of the genus Megalopsalis (Opiliones, Neopilionidae), with the description of seven new species. ZooKeys 328, 59-117.

Taylor, C.K., and Hunt, G.S. (2009) New genus of Megalopsalidinae (Arachnida:

Opiliones: Monoscutidae) from north-eastern Australia. Zootaxa(2130), 41-59.

Wheeler, W.C. (1996) Optimization alignment: the end of multiple sequence alignment in phylogenetics? Cladistics 12, 1-9.

Wheeler, W.C., Aagesen, L., Arango, C.P., Faivovich, J., Grant, T., D'Haese, C.A., Janies, D., Smith, W.L., Varon, A., and Giribet, G. (2006) 'Dynamic homology and phylogenetic systematics: a unified approach using POY.' (American Museum of Natural History)

Wheeler, W.C., Lucaroni, N., Hong, L., Crowley, L.M., and Varón, A. (2014) POY version 5: phylogenetic analysis using dynamic homologies under multiple optimality criteria. Cladistics(doi:10.1111/cla.12083).

White, A. (1849a) Descriptions of apparently new species of Aptera from New Zealand. Proceedings of the Zoological Society of London 17, 3-6.

Proceedings of the Zoological Society of London 17, 3-6. 
1104 Whiting, M.F., Carpenter, J.M., Wheeler, Q.D., and Wheeler, W.C. (1997) The 1105 Strepsiptera problem: phylogeny of the holometabolous insect orders inferred from 18S 1106 and 28S ribosomal DNA sequences and morphology. Systematic Biology 46, 1-68.

1107

1108 Yang, Z. (1993) Maximum likelihood estimation of phylogeny from DNA sequences

1109 when substitution rates differ over sites. Molecular Biology and Evolution 10, 1396-1401.

1110

1111

1112 


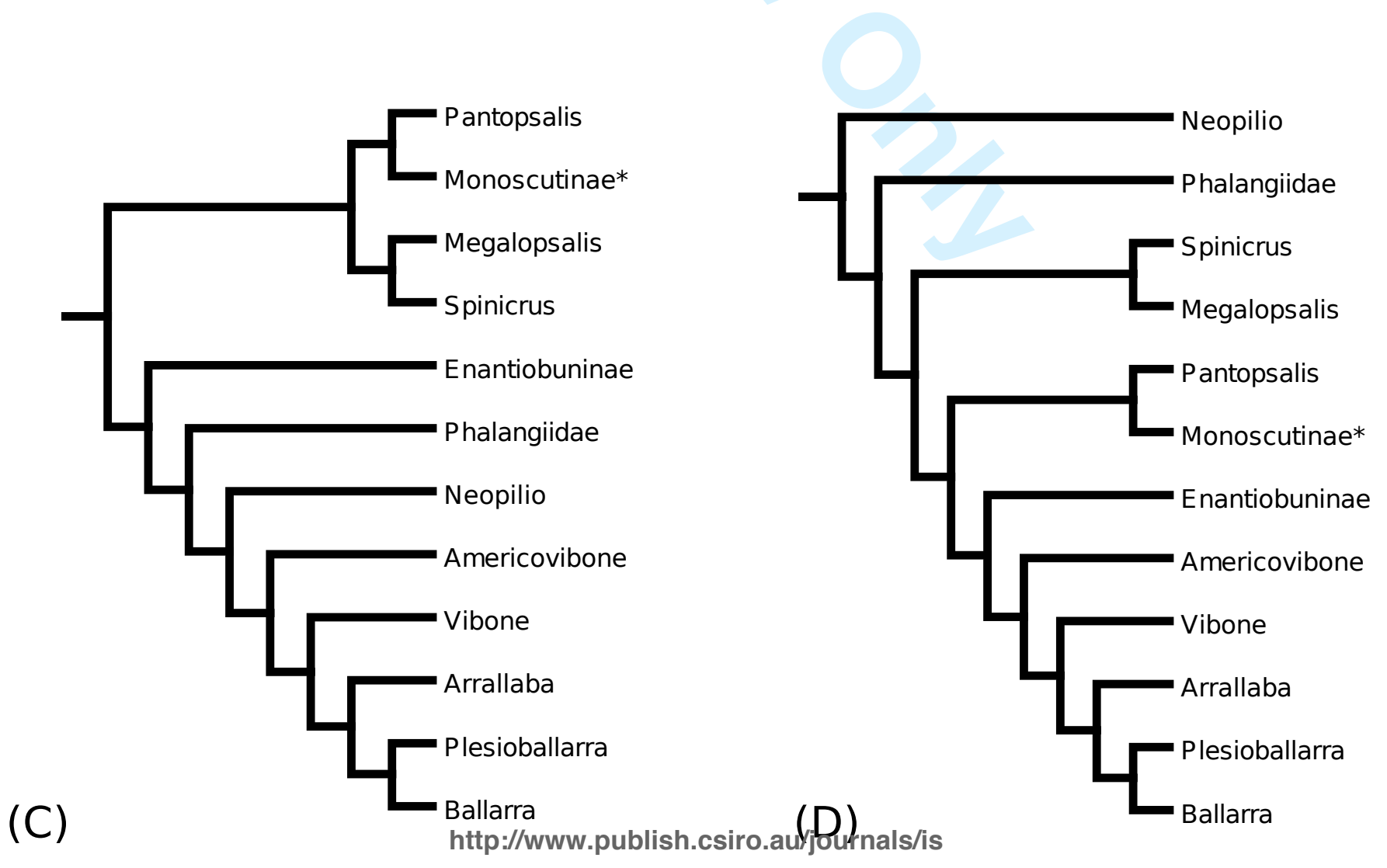

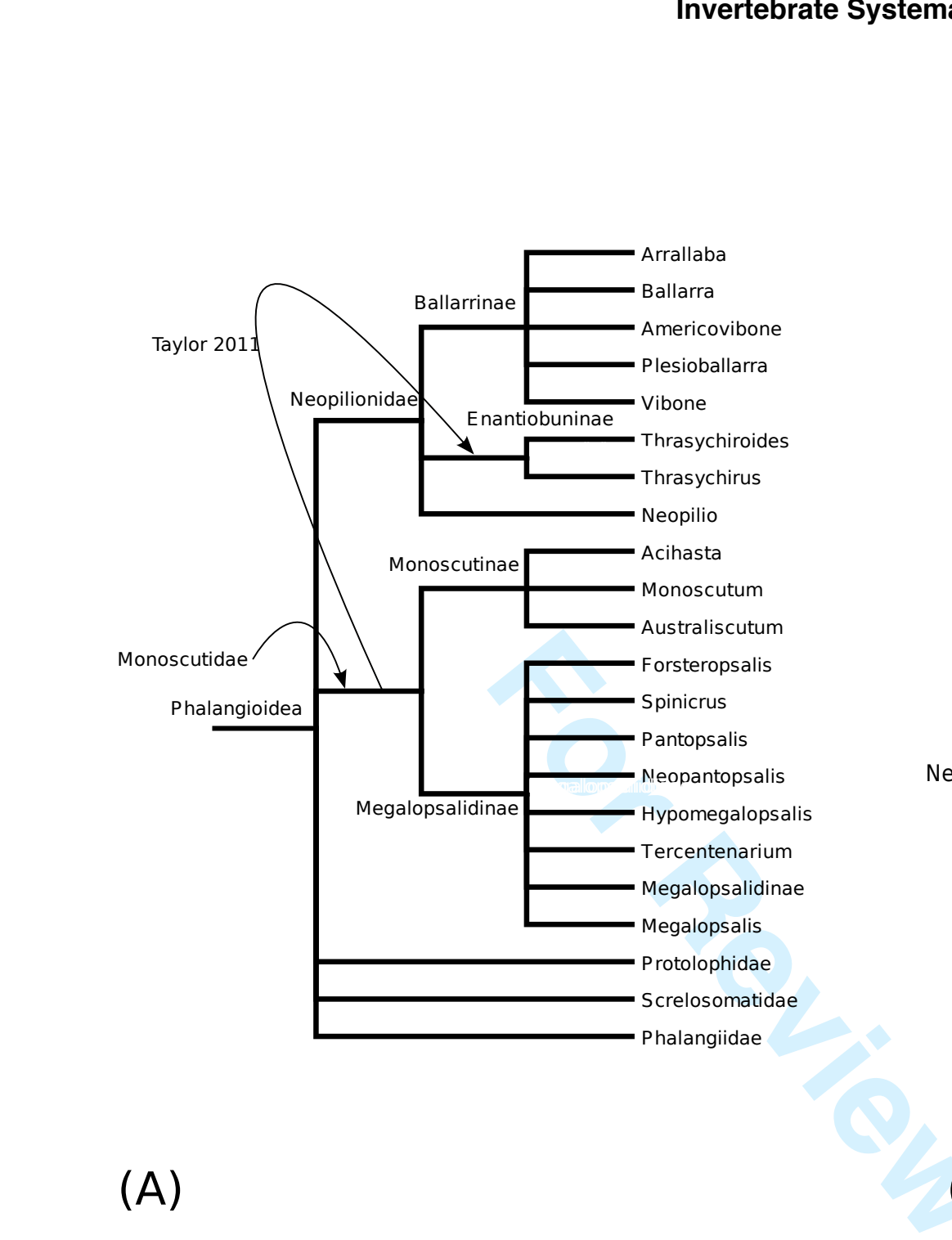

(A)

(B) 

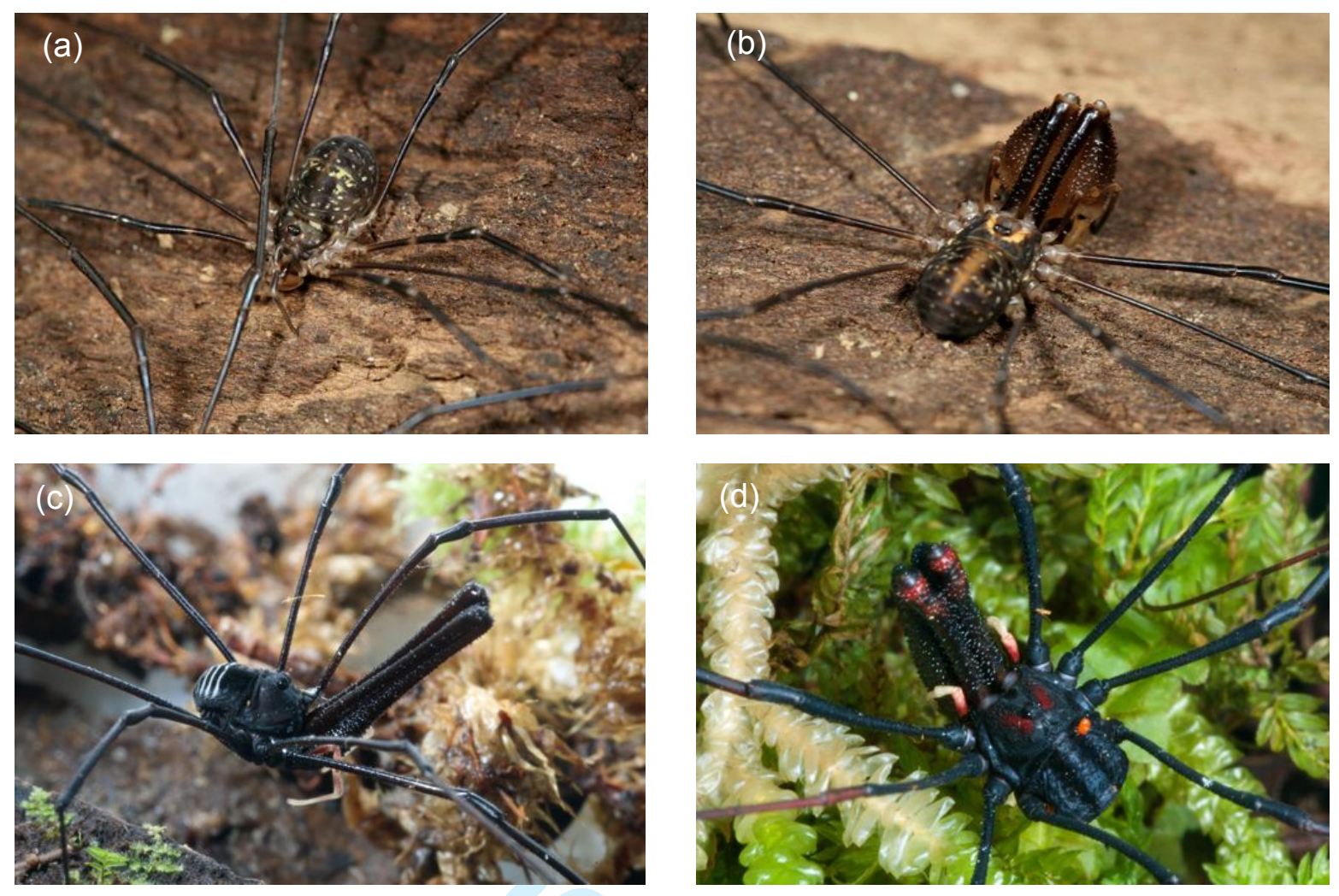

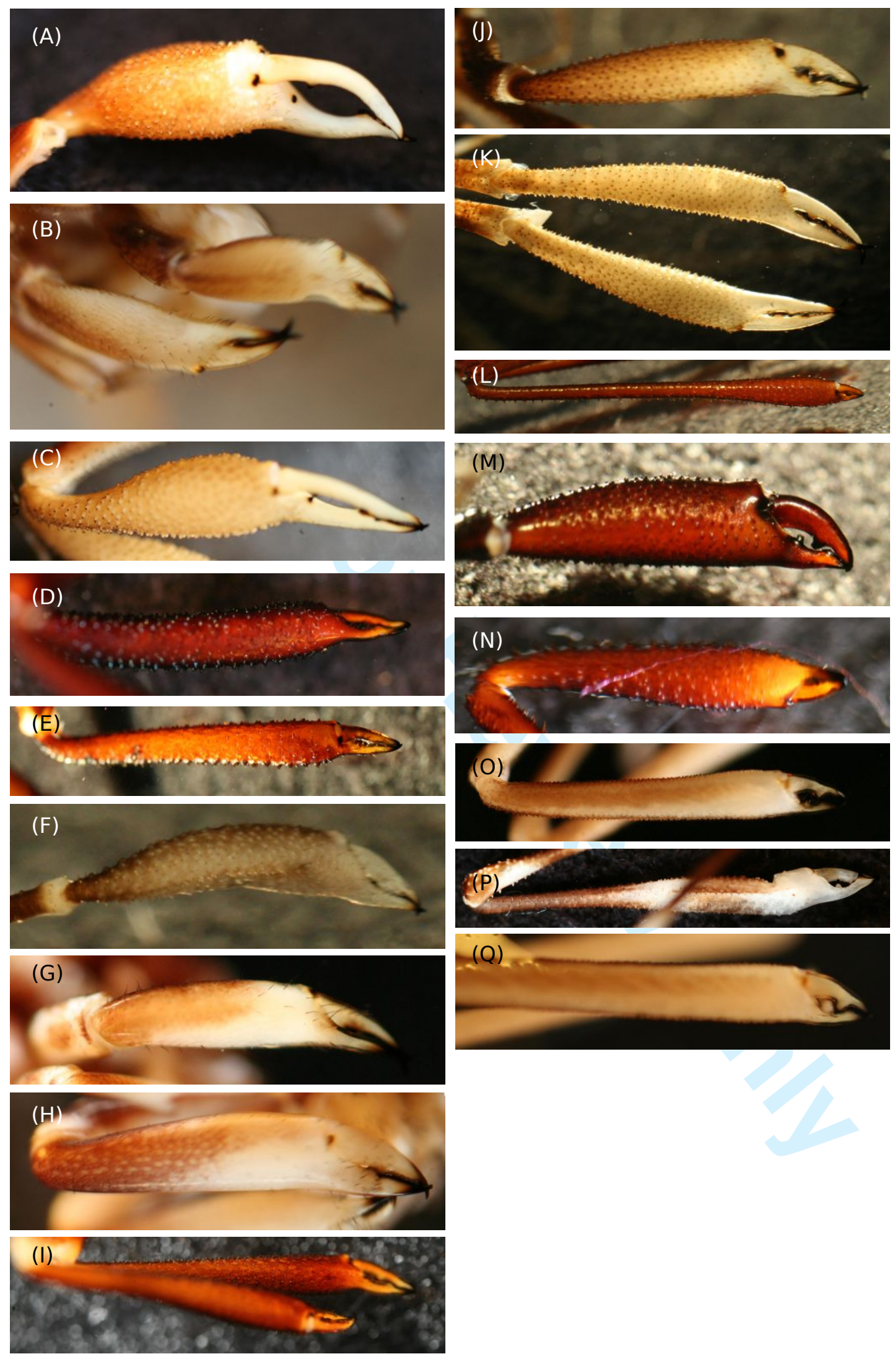

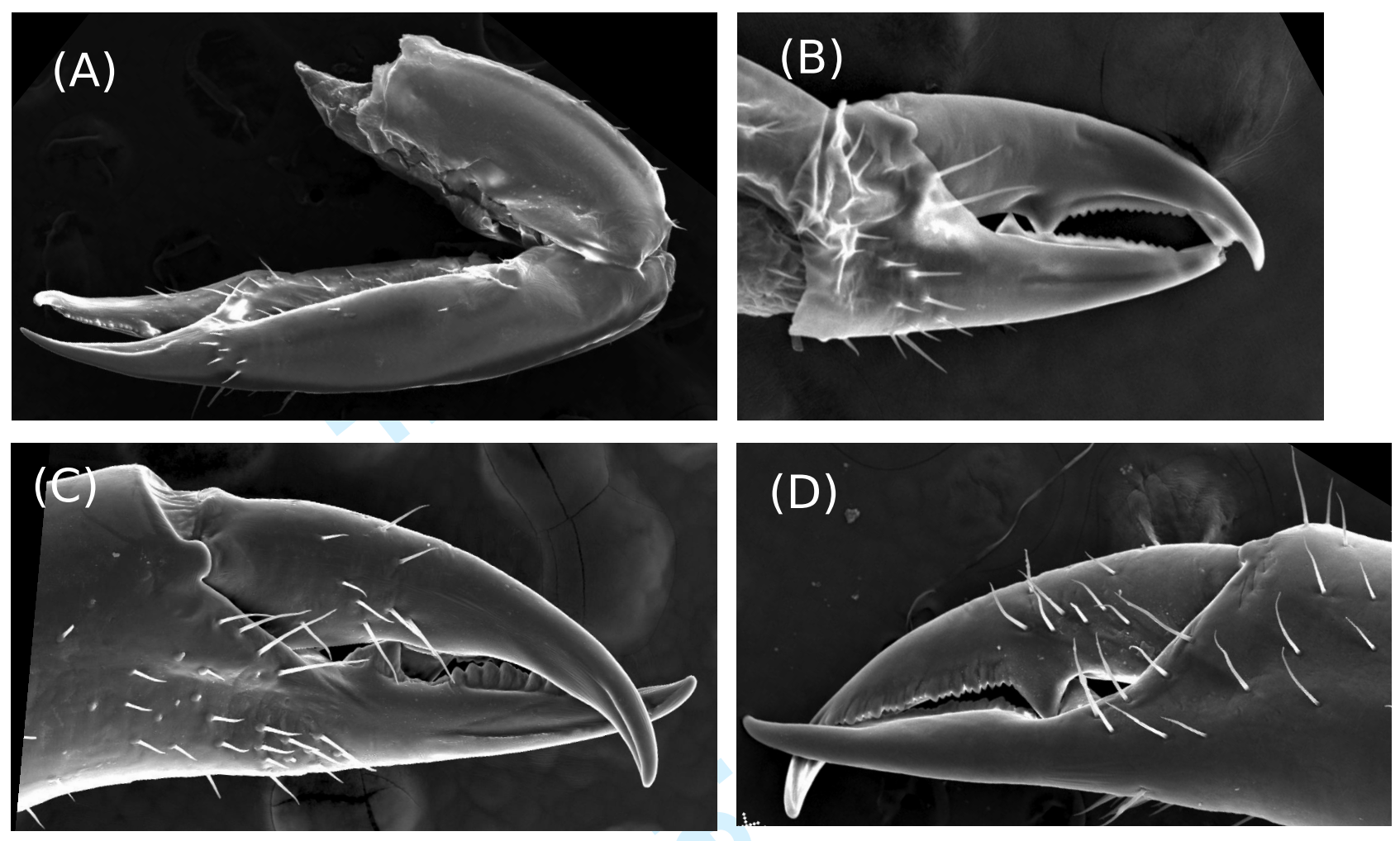


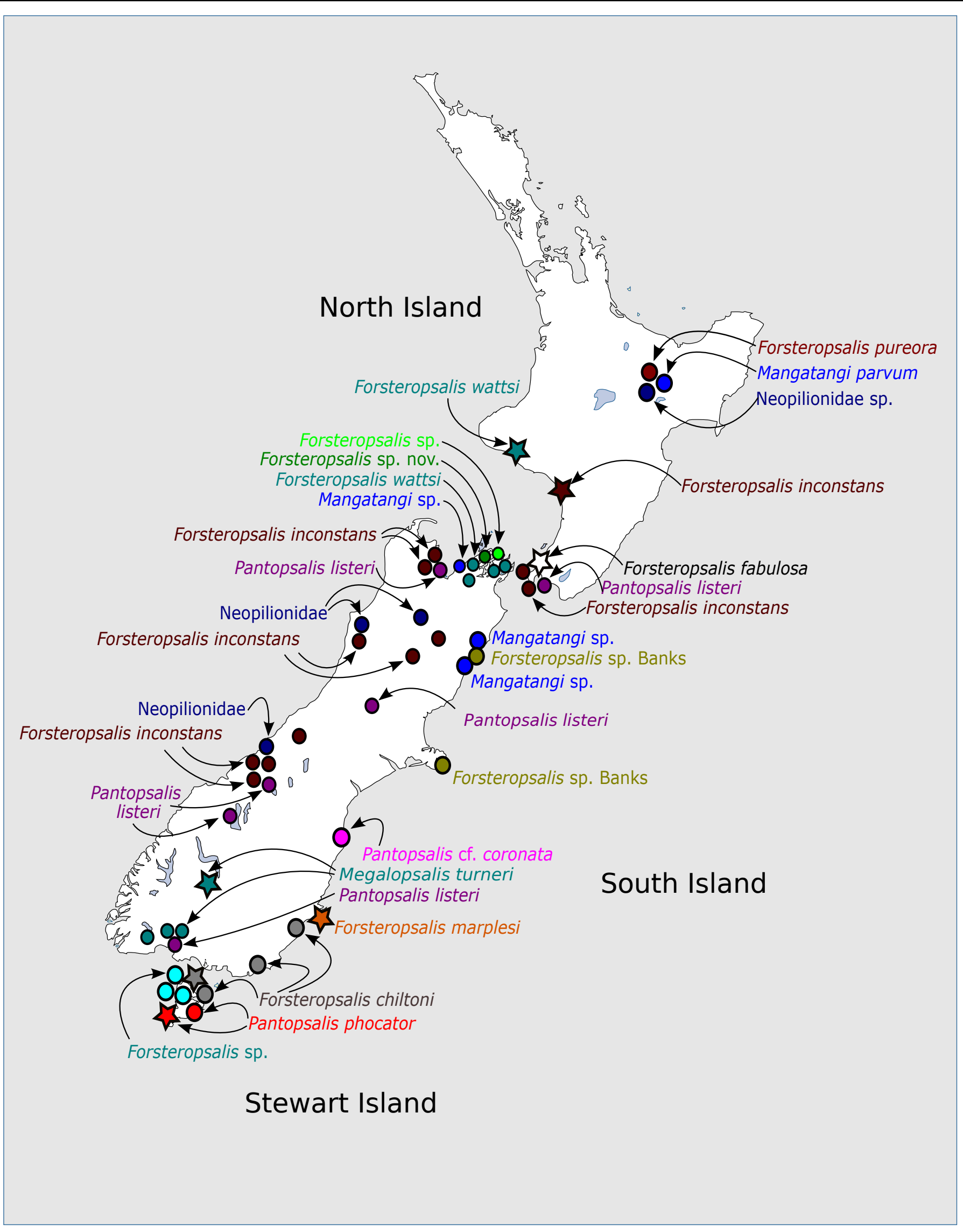




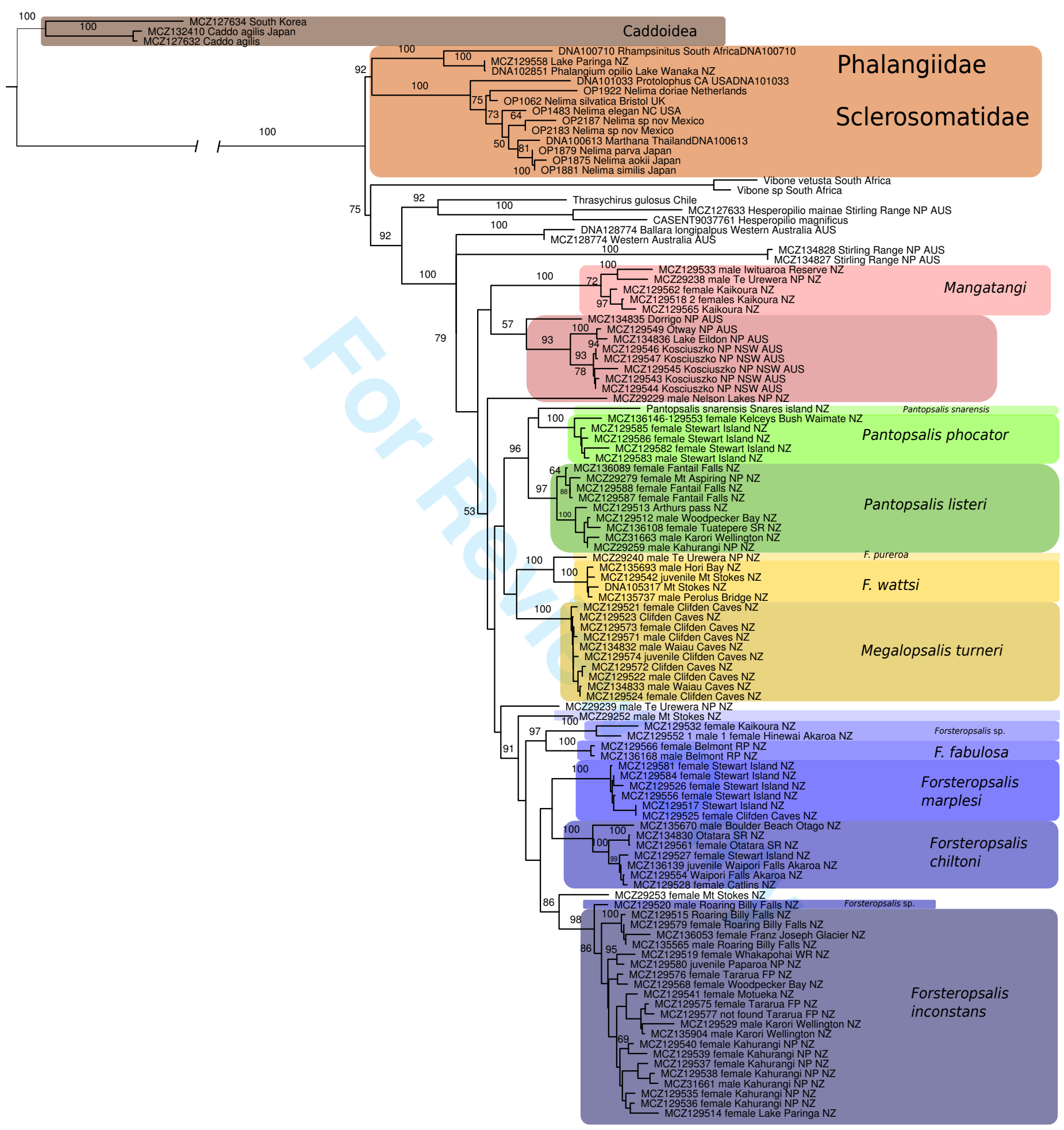




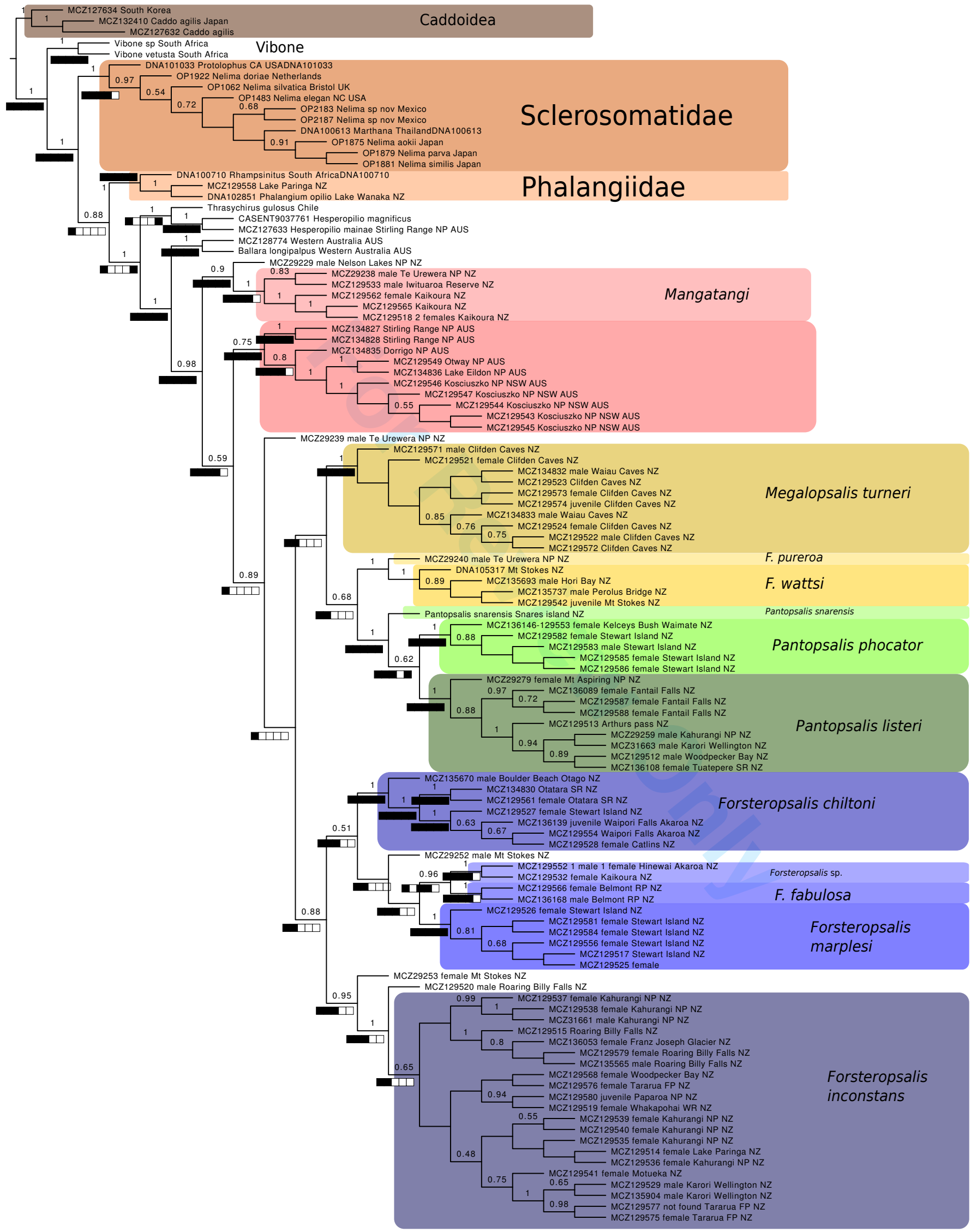



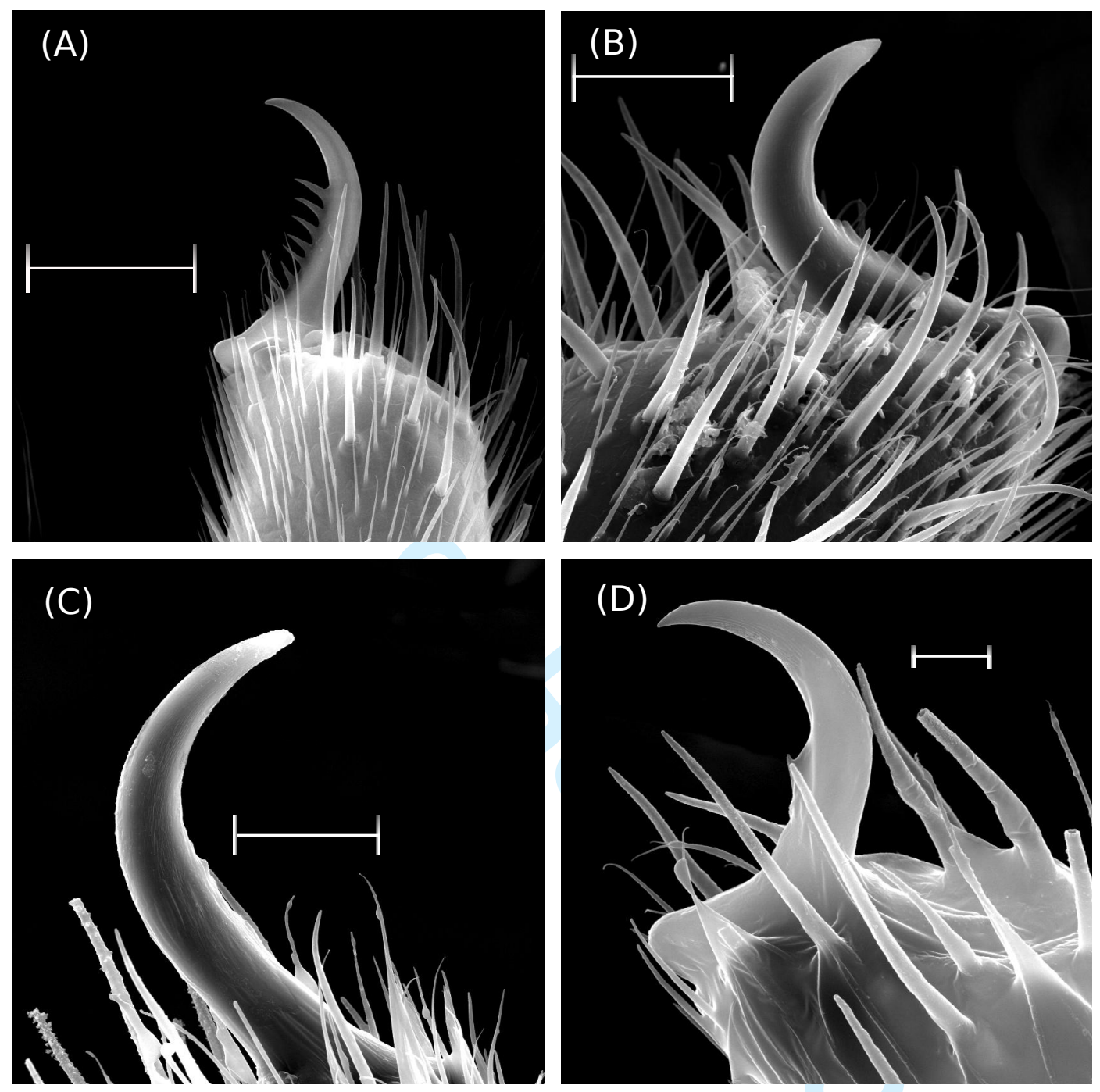

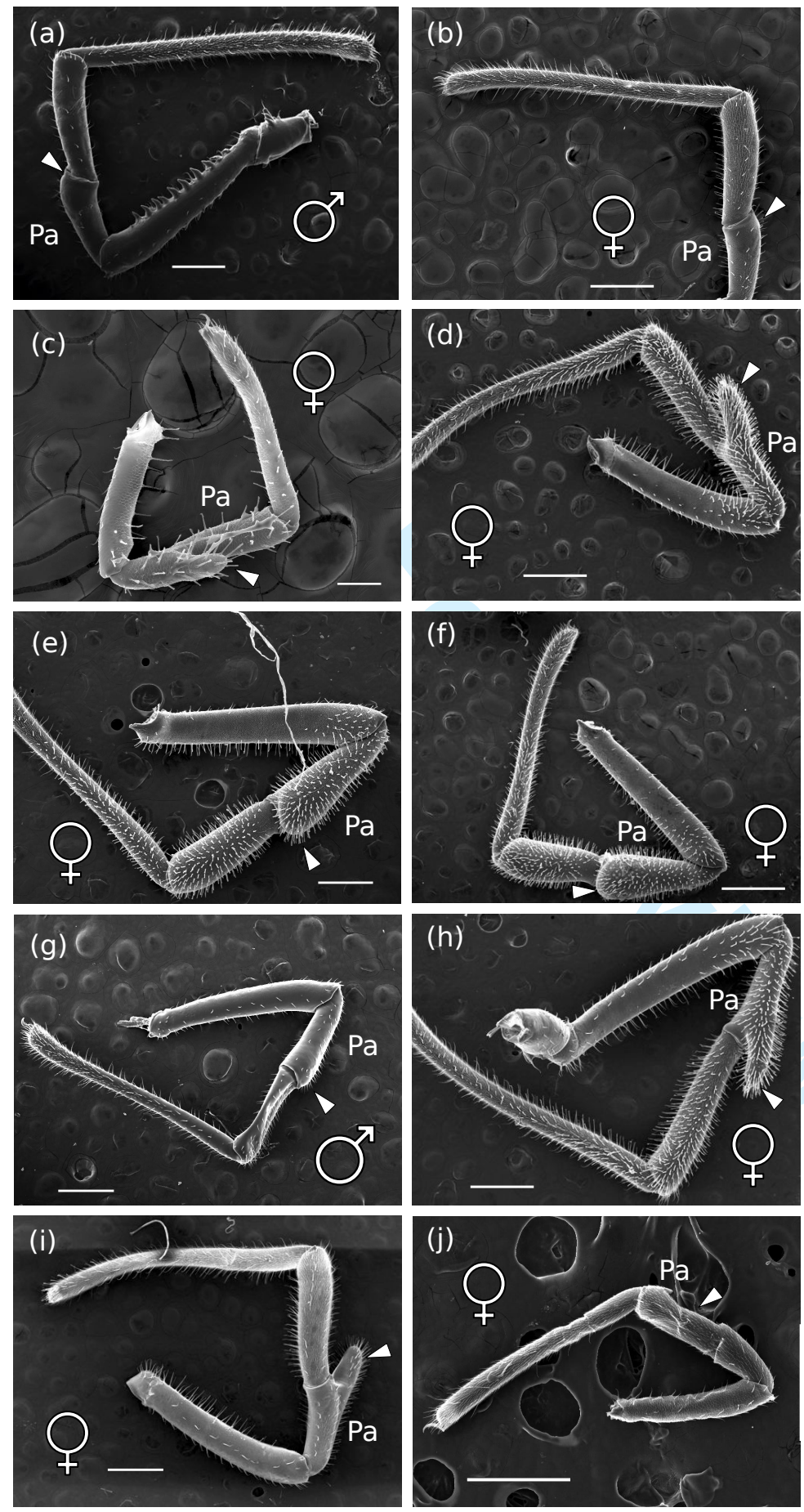

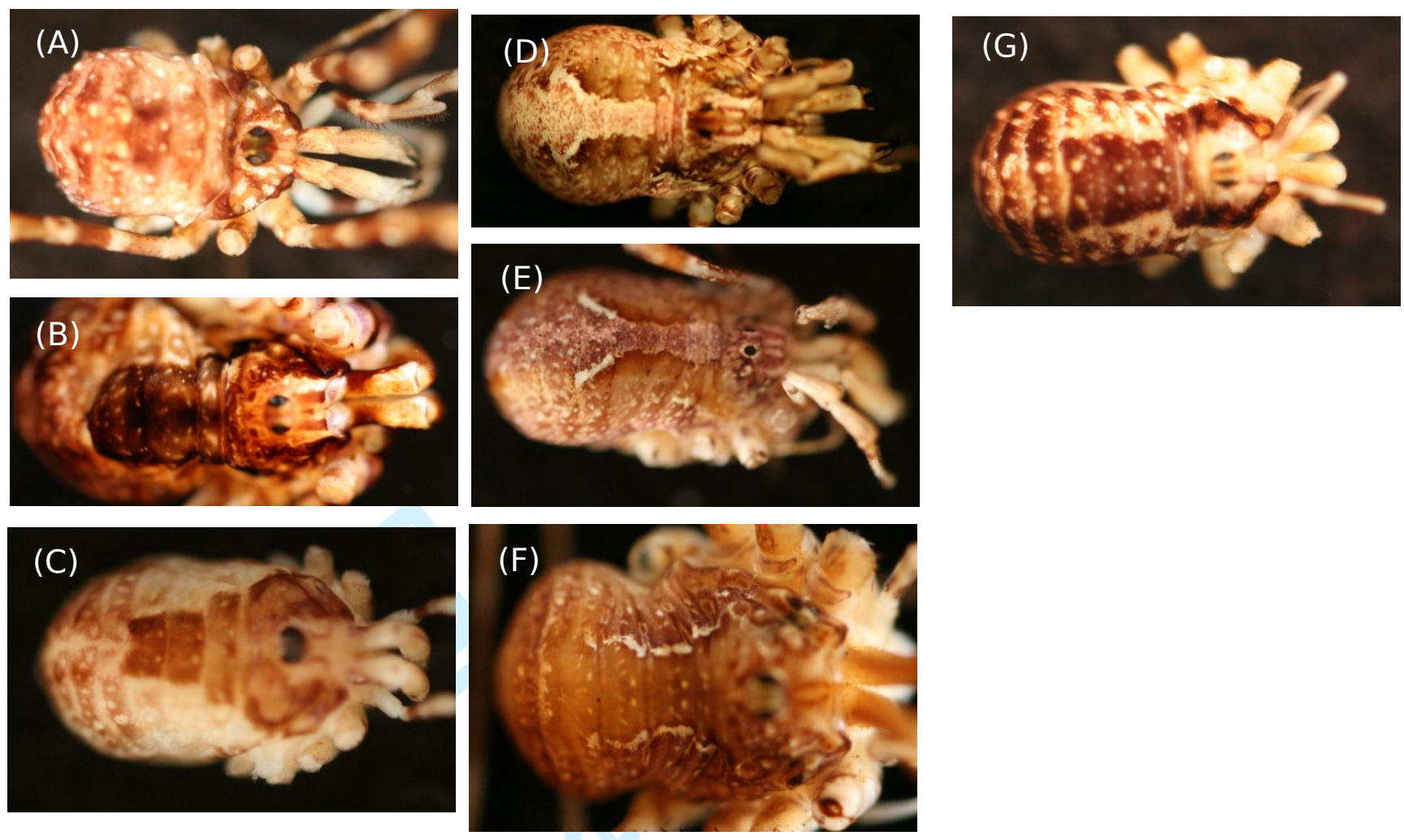
Sheet1

\begin{tabular}{|c|c|c|c|c|}
\hline Voucher & Descriptor & Other catalog number / Reference & Lat & Long \\
\hline AH.001078 & Pantopsalis snar Snares Island, NZ & $\mathrm{n} / \mathrm{a}$ & -8.0205 & 166.6113 \\
\hline CASENT-90: & Hesperopilio magnificus & from Giribet and Groh (unpublished) & & \\
\hline MCZ127632 & Caddo agilis unknown & from Giribet and Groh (unpublished) & unknown & unknown \\
\hline MCZ127633 & Hesperopilio ma Stirling Range NP & from Giribet and Groh (unpublished) & -34.3750 & 118.2567 \\
\hline MCZ127634 & Caddo pepperell South Korea & $\mathrm{n} / \mathrm{a}$ & 35.2758 & 127.6178 \\
\hline MCZ128774 & Ballara sp Western Australia & DNA128774 & -32.6000 & 116.2000 \\
\hline MCZ129512 & Woodpecker Bay I & NDNA102786 & -42.2172 & 171.3897 \\
\hline MCZ129513 & Pantopsalis sp Arthurs pass NZ & DNA102800 & -43.2669 & 171.7097 \\
\hline MCZ129514 & Forsteropsalis s Lake Paringa NZ & DNA102823 & -43.595 & 169.8247 \\
\hline MCZ129515 & Forsteropsalis s Roaring Billy Falls & DNA102840 & -43.2989 & 169.2881 \\
\hline MCZ129517 & Forsteropsalis s Stewart Island NZ & DNA102882 & -46.6647 & 168.2350 \\
\hline MCZ129518 & Mangatangi sp Kaikoura NZ & DNA102921 & -42.0539 & 173.4006 \\
\hline MCZ129519 & Forsteropsalis s Whakapohai WR N & J DNA 105050 & -43.56 & 169.0811 \\
\hline MCZ129520 & Forsteropsalis s Roaring Billy Falls & DNA105051 & -43.2806 & 169.5097 \\
\hline MCZ129521 & Megalopsalis tur Clifden Caves NZ & DNA105144 & -46.0919 & 167.4972 \\
\hline MCZ129522 & Forsteropsalis s Clifden Caves NZ & DNA105146 & -46.0919 & 167.4972 \\
\hline MCZ129523 & Forsteropsalis s Clifden Caves NZ & DNA105149 & -46.0919 & 167.4972 \\
\hline MCZ129524 & Forsteropsalis s Clifden Caves NZ & DNA105150 & -46.0919 & 167.4972 \\
\hline MCZ129525 & Forsteropsalis s Clifden Caves NZ & DNA105152 & -46.0919 & 167.4972 \\
\hline MCZ129526 & Forsteropsalis s Stewart Island NZ & DNA105153 & -46.8347 & 168.5381 \\
\hline MCZ129527 & Forsteropsalis s Stewart Island NZ & DNA105162 & -46.8347 & 168.5381 \\
\hline MCZ129528 & Forsteropsalis s Catlins NZ & DNA105197 & -46.4128 & 169.8039 \\
\hline MCZ129529 & Forsteropsalis s Karori Wellington & I DNA105355 & -41.0661 & 174.5325 \\
\hline MCZ129532 & Forsteropsalis s Kaikoura NZ & DNA104787 & -42.8953 & 173.3422 \\
\hline MCZ129533 & Mangatangi sp Iwituaroa Reserve & I DNA105971 & -41.8508 & 173.2486 \\
\hline MCZ129535 & Forsteropsalis s Kahurangi NP NZ & DNA105973 & -41.4081 & 172.4922 \\
\hline MCZ129536 & Forsteropsalis s Kahurangi NP NZ & DNA105974 & -41.4081 & 172.4922 \\
\hline MCZ129537 & Forsteropsalis s Kahurangi NP NZ & DNA105975 & -41.4081 & 172.4922 \\
\hline MCZ129538 & Forsteropsalis s Kahurangi NP NZ & DNA105976 & -41.4081 & 172.4922 \\
\hline MCZ129539 & Forsteropsalis s Kahurangi NP NZ & DNA105978 & -41.4081 & 172.4922 \\
\hline MCZ129540 & Forsteropsalis s Kahurangi NP NZ & DNA105979 & -41.4081 & 172.4922 \\
\hline MCZ129541 & Forsteropsalis s Motueka NZ & DNA105980 & -41.8064 & 172.3867 \\
\hline MCZ129542 & Forsteropsalis s Mt Stokes NZ & DNA105981 & -41.2031 & 174.2922 \\
\hline MCZ129543 & Spinicrus sp Kosciuszko NP NS & DNA105982 & -36.0825 & 148.7389 \\
\hline MCZ129544 & Kosciuszko NP NS & DNA105983 & -36.0825 & 148.7389 \\
\hline MCZ129545 & Kosciuszko NP NS & DNA105984 & -36.0825 & 148.7389 \\
\hline MCZ129546 & Kosciuszko NP NS & DNA105985 & -36.0825 & 148.7389 \\
\hline MCZ129547 & Kosciuszko NP NS & DNA105986 & -36.0825 & 148.7389 \\
\hline MCZ129549 & Spinicrus sp $\quad$ Otway NP AUS & DNA105988 & -38.1786 & 143.7928 \\
\hline MCZ129552 & Forsteropsalis s Hinewai Akaroa $\mathrm{N}$ & ¿DNA102910 & -43.6967 & 173.7053 \\
\hline MCZ129554 & Forsteropsalis s Waipori Falls Akar & DNA102901 & -45.2983 & 169.2831 \\
\hline MCZ129556 & Forsteropsalis s Stewart Island NZ & DNA102897 & -46.9147 & 168.0017 \\
\hline MCZ129558 & Phalangium opil Lake Paringa NZ & DNA102825 & -43.71 & 169.4970 \\
\hline MCZ129561 & Forsteropsalis s Otatara SR NZ & DNA100784 & -46.0072 & 168.0049 \\
\hline
\end{tabular}

Page 1 
Sheet1

\begin{tabular}{|c|c|c|c|c|}
\hline MCZ129562 & Mangatangi sp Kaikoura NZ & DNA102915 & -42.6878 & 173.7469 \\
\hline MCZ129565 & Mangatangi par 1 Kaikoura NZ & DNA102919 & -42.8953 & 173.3422 \\
\hline MCZ129566 & 5 Forsteropsalis s Belmont RP NZ & DNA102929 & -41.3492 & 174.9275 \\
\hline MCZ129568 & Forsteropsalis s Woodpecker Bay $\mathrm{N}$ & NDNA104785 & -42.2172 & 171.3897 \\
\hline MCZ129571 & Forsteropsalis s Clifden Caves NZ & DNA105147 & -46.0919 & 167.4972 \\
\hline MCZ129572 & Forsteropsalis s Clifden Caves NZ & DNA105148 & -46.0919 & 167.4972 \\
\hline MCZ129573 & Forsteropsalis s Clifden Caves NZ & DNA105145 & -46.0919 & 167.4972 \\
\hline MCZ129574 & Forsteropsalis s Clifden Caves NZ & DNA105151 & -46.0919 & 167.4972 \\
\hline MCZ129575 & Forsteropsalis s Tararua FP NZ & DNA105528 & -40.2828 & 175.8169 \\
\hline MCZ129576 & Forsteropsalis s Tararua FP NZ & DNA105527 & -40.2828 & 175.8169 \\
\hline MCZ129577 & Forsteropsalis s Tararua FP NZ & DNA105526 & -40.2828 & 175.8169 \\
\hline MCZ129578 & Forsteropsalis s Mt Stokes NZ & DNA105317 & -41.09 & 174.1381 \\
\hline MCZ129579 & Forsteropsalis s Roaring Billy Falls & DNA105056 & -43.2806 & 169.5097 \\
\hline MCZ129580 & Forsteropsalis s Paparoa NP NZ & DNA105029 & -42.555 & 171.5556 \\
\hline MCZ129581 & Forsteropsalis s Stewart Island NZ & DNA104789 & -46.9147 & 168.0017 \\
\hline MCZ129582 & Pantopsalis sp Stewart Island NZ & DNA104791 & -46.9147 & 168.0017 \\
\hline MCZ129583 & Pantopsalis sp Stewart Island NZ & DNA104792 & -46.9147 & 168.0017 \\
\hline MCZ129584 & Forsteropsalis s Stewart Island NZ & DNA104793 & -46.9147 & 168.0017 \\
\hline MCZ129585 & Pantopsalis sp Stewart Island NZ & DNA104794 & -46.9147 & 168.0017 \\
\hline MCZ129586 & 5 Pantopsalis sp Stewart Island NZ & DNA104795 & -46.9147 & 168.0017 \\
\hline MCZ129587 & Pantopsalis sp Fantail Falls NZ & DNA104797 & -44.6011 & 169.1897 \\
\hline MCZ129588 & Pantopsalis sp Fantail Falls NZ & DNA104798 & -44.6011 & 169.1897 \\
\hline MCZ132410 & Caddo agilis Mt Takao JAPAN & DNA101716 from Giribet and Groh (unpublishe & 35.6344 & 139.2412 \\
\hline MCZ132934 & I Vibone vetusta South Africa & DNA106709 & -33.9856 & 18.4013 \\
\hline MCZ132935 & 5 Vibone sp. South Africa & DNA106708 & -33.9673 & 18.9431 \\
\hline MCZ133900 & Rhampsinitu s sp South Africa & DNA100710 from Giribet et al 2010 & -33.9792 & 18.4500 \\
\hline MCZ134827 & Spinicrus sp Stirling Range NP & DNA106783 & -34.3803 & 118.2503 \\
\hline MCZ134828 & Stirling Range NP & DNA106784 & -34.3803 & 118.2503 \\
\hline MCZ134830 & Forsteropsalis s Otatara SR NZ & DNA100782 & -46.2069 & 168.1547 \\
\hline MCZ134832 & Forsteropsalis s Waiau Caves NZ & DNA100783 from Boyer 2007 & -46.0003 & 167.0123 \\
\hline MCZ134833 & Forsteropsalis s Waiau Caves NZ & DNA100785 & -46.0003 & 167.0123 \\
\hline MCZ134835 & 5 Spinicrus sp Dorrigo NP AUS & DNA105989 & -30.0644 & 152.7186 \\
\hline MCZ134836 & Lake Eildon NP AI & LNA105990 & -37.6586 & 146.0931 \\
\hline MCZ134862 & Marthana sp. Thailand & DNA100613 from Giribet et al 2010 & unknown & unknown \\
\hline MCZ135565 & Forsteropsalis s Roaring Billy Falls & DNA105073 & -43.2806 & 169.5097 \\
\hline MCZ135670 & Forsteropsalis s Boulder Beach Ota & !̨DNA105202 & -45.8328 & 170.6233 \\
\hline MCZ135693 & Forsteropsalis s Hori Bay NZ & DNA105227 & -41.2639 & 173.0136 \\
\hline MCZ135737 & Forsteropsalis s Perolus Bridge NZ & DNA105280 & -41.9264 & 173.3761 \\
\hline MCZ135904 & Forsteropsalis s Karori Wellington & I DNA105459 & -41.4364 & 174.1625 \\
\hline MCZ136053 & Forsteropsalis s Franz Joseph Glaci & is DNA102811 & -43.5403 & 170.0694 \\
\hline MCZ136089 & Pantopsalis sp Fantail Falls NZ & DNA102848 & -44.6011 & 169.1897 \\
\hline MCZ136092 & Phalangium opil Lake Wanaka NZ & DNA102851 & -44.40 & 169.1873 \\
\hline MCZ136108 & Pantopsalis sp Tuatepere SR NZ & DNA102868 & -46.5683 & 167.4114 \\
\hline MCZ136139 & Forsteropsalis s Waipori Falls Akar & DNA102900 & -45.2983 & 169.2831 \\
\hline MCZ136146 & 5 Pantopsalis sp Waimate NZ & DNA102907 & -44.70 & 170.9675 \\
\hline MCZ136168 & Forsteropsalis s Belmont RP NZ & DNA105996 & -41.3492 & 174.9275 \\
\hline MCZ29229 & Neopilionidae si Nelson Lakes NP N & $\mathrm{N} n / \mathrm{a}$ & -41.82 & 172.8079 \\
\hline MCZ29238 & Mangatangi $\mathrm{sp}$ Te Urewera NP NZ & & -38.7254 & 177.1650 \\
\hline MCZ29239 & Neopilionidae sl Te Urewera NP NZ & $\mathrm{z} / \mathrm{a}$ & -38.7273 & 177.1652 \\
\hline MCZ29240 & Forsteropsalis s Te Urewera NP NZ & $\mathrm{Z} / \mathrm{a}$ & -38.7273 & 177.1652 \\
\hline MCZ29252 & Forsteropsalis s Mt Stokes NZ & $\mathrm{n} / \mathrm{a}$ & -41.09 & 174.1382 \\
\hline
\end{tabular}

Page 2

http://www.publish.csiro.au/journals/is 
Sheet1

\begin{tabular}{|c|c|c|c|}
\hline MCZ29253 & Forsteropsalis s Mt Stokes NZ & -41.09 & 174.1382 \\
\hline MCZ29259 & Pantopsalis sp Kahurangi NP NZ n/a & -41.18 & 172.7302 \\
\hline MCZ29279 & Pantopsalis sp Mt Aspiring NP NZn/a & -44.49 & 168.7874 \\
\hline MCZ31661 & Forsteropsalis s Kahurangi NP NZ DNA105977 & -41.4081 & 172.4922 \\
\hline MCZ31663 & Pantopsalis sp Karori Wellington I DNA100702 from Giribet et al 2010 & -41.0044 & 174.5125 \\
\hline OP1062 & Nelima silvatica Bristol UK $\quad$ from Hedin et al 2012 & & \\
\hline OP1152 & Thrasychirus gui Chiloe, CHILE & & \\
\hline OP1483 & Nelima elegans North Carlina USA from Hedin et al 2012 & & \\
\hline OP1875 & Honshu JAPAN from Hedin et al 2012 & & \\
\hline OP1879 & from Hedin et al 2012 & & \\
\hline OP1881 & from Hedin et al 2012 & & \\
\hline OP1922 & NETHERLANDS from Hedin et al 2012 & & \\
\hline OP2183 & Oaxaca, MEXICO from Hedin et al 2012 & & \\
\hline OP2187 & Oaxaca, MEXICO from Hedin et al 2012 & & \\
\hline
\end{tabular}

Page 3

http://www.publish.csiro.au/journals/is 
Sheet1

Genbank

\begin{tabular}{|c|c|c|c|c|c|}
\hline $\begin{array}{l}\text { Collecto } \\
\text { rs }\end{array}$ & $\begin{array}{l}\text { Vouch } \\
\text { er } \\
\text { URL }\end{array}$ & Date & COI & $18 \mathrm{~S}$ & $28 \mathrm{~S}$ \\
\hline A. Kusab & & 3.XII.2013 & $\begin{array}{c}\text { KJ920342 } \\
--\end{array}$ & $\begin{array}{c}-- \\
\text { KF963312.1 }\end{array}$ & $\begin{array}{c}-- \\
\text { KF955599.1 }\end{array}$ \\
\hline Prashant & ؛http://n & 2000 & -- & KF963310.1 & KF955597.1 \\
\hline Michael F & Fhttp://n & 24.V.2011 & -- & KF963313.1 & KF955600.1 \\
\hline Mark S. I & http://n & 20.06 .2010 & -- & KF963311.1 & KF955598.1 \\
\hline M. Lythe & http://n & 30.VII.2013 & KJ871355 & KJ871431 & KJ871516 \\
\hline G. Giribe & $\mathrm{http}: / / \mathrm{r}$ & 12.II.2008 & KJ871372 & KJ871432 & KJ871579 \\
\hline G. Giribe & thttp://n & 13.II.2008 & KJ871362 & KJ871433 & KJ871580 \\
\hline G. Giribe & thttp://n & 15.II.2008 & KJ871366 & KJ871434 & KJ871517 \\
\hline G. Giribe & thttp://n & 15.II.2008 & KJ871364 & KJ871435 & KJ871518 \\
\hline G. Giribe & thttp://n & 17.II.2008 & KJ871373 & KJ871436 & KJ871519 \\
\hline P. Paquin & http://n & 20.II. 2008 & KJ871395 & KJ871437 & KJ871572 \\
\hline S. Velez & http://n & 23.XII.2009 & KJ871404 & KJ871438 & KJ871520 \\
\hline S. Velez & http://n & 24.XII.2009 & KJ871413 & KJ871439 & KJ871521 \\
\hline S. Velez & http://n & 27.XII.2009 & KJ871406 & KJ871440 & KJ871522 \\
\hline S. Velez & http://n & 27.XII.2009 & KJ871415 & KJ871441 & KJ871523 \\
\hline S. Velez & http://n & 27.XII.2009 & KJ871423 & KJ871442 & KJ871524 \\
\hline S. Velez & http://n & 27.XII.2009 & KJ871408 & KJ871443 & KJ871525 \\
\hline S. Velez & http://n & 27.XII.2009 & KJ871409 & -- & -- \\
\hline S. Velez & http://n & 28.XII.2009 & KJ871410 & KJ871444 & KJ871526 \\
\hline S. Velez & $\mathrm{http}: / / \mathrm{r}$ & 28.XII.2009 & KJ871411 & KJ871445 & KJ871527 \\
\hline S. Velez & http://n & 29.XII.2009 & KJ871412 & KJ871446 & KJ871528 \\
\hline S. Velez & http://n & 7.I.2010 & KJ871420 & KJ871447 & KJ871529 \\
\hline P. Paquin & http://n & 20.II.2008 & KJ871397 & KJ871448 & KJ871530 \\
\hline N. Scharf & f http://n & 10.III.2010 & KJ871386 & KJ871449 & KJ871573 \\
\hline N. Scharf & f http://n & 7.III.2010 & KJ871402 & KJ871450 & KJ871531 \\
\hline N. Scharf & f http://n & 7.III.2010 & KJ871392 & KJ871451 & KJ871532 \\
\hline N. Scharf & f http://n & 7.III.2010 & KJ871428 & KJ871452 & KJ871533 \\
\hline N. Scharf & f http://n & 7.III.2010 & KJ871429 & KJ871453 & KJ871534 \\
\hline N. Scharf & f http://n & 7.III.2010 & KJ871361 & KJ871454 & KJ871535 \\
\hline N. Scharf & f http://n & 7.III.2010 & KJ871393 & KJ871455 & KJ871536 \\
\hline N. Scharf & f http://n & 8.III.2010 & KJ871430 & KJ871456 & KJ871537 \\
\hline N. Scharf & f http://n & 11.III.2010 & KJ871401 & KJ871457 & KJ871538 \\
\hline N. Scharf & f http://n & 23.XII.2010 & KJ871387 & KJ871458 & KJ871595 \\
\hline N. Scharf & f http://n & 23.XII.2010 & KJ871388 & KJ871459 & KJ871596 \\
\hline N. Scharf & f http://n & 23.XII.2010 & KJ871359 & KJ871460 & KJ871597 \\
\hline N. Scharf & f http://n & 23.XII.2010 & KJ871360 & KJ871461 & KJ871598 \\
\hline N. Scharf & f http://n & 23.XII. 2010 & KJ871427 & KJ871462 & KJ871599 \\
\hline N. Scharf & f http://n & 28.XII.2010 & KJ871389 & KJ871463 & KJ871600 \\
\hline P. Paquin & http://n & 19.II.2008 & KJ871399 & KJ871464 & KJ871539 \\
\hline G. Giribe & http://n & 17.II.2008 & KJ871375 & KJ871465 & KJ871540 \\
\hline G. Giribe & thttp://n & 17.II.2008 & KJ871376 & KJ871466 & KJ871541 \\
\hline Gonzalo & ( http://n & 15.II.2008 & KJ871363 & KJ871467 & KJ871593 \\
\hline C.J. Vink & http://n & 4.X.2002 & KJ871356 & -- & KJ871542 \\
\hline
\end{tabular}

Page 4 


\begin{tabular}{|c|c|c|c|c|}
\hline P. Paquin http://n & 20.II.2008 & KJ871394 & KJ871468 & KJ871574 \\
\hline P. Paquin http://n & 20.II.2008 & KJ871400 & KJ871469 & KJ871575 \\
\hline Paquin http://n & 21.II.2008 & J871396 & -- & KJ871543 \\
\hline Giribethttp://n & 12.II.2008 & J871369 & KJ871470 & KJ871544 \\
\hline Velez http://n 2 & 27.XII.2009 & KJ871416 & KJ871471 & KJ871545 \\
\hline Velez http://n 2 & 27.XII.2009 & & KJ871472 & UJ871546 \\
\hline Velez http://n 2 & 27.XII.2009 & KJ871407 & KJ871473 & KJ871547 \\
\hline Velez http://n 2 & 27.XII.2009 & KJ871403 & KJ871474 & KJ871548 \\
\hline Velez http://n & 9.I.2010 & KJ871391 & KJ871475 & KJ871549 \\
\hline S. Velez http://n & 9.I.2010 & & & 71550 \\
\hline S. Velez http://n & 9.I.2010 & & KJ871477 & 551 \\
\hline Sebastián http://n & 6.I.2010 & & -- & 552 \\
\hline S. Velez http://n 2 & 24.XII.2009 & & KJ871478 & 553 \\
\hline S. Velez http://n 2 & 21.XII.2009 & & & 1554 \\
\hline G. Giribethttp://n & 17.II.2008 & & KJ871 & 1555 \\
\hline Giribethttp://n & 17.II.2008 & & & 1581 \\
\hline Giribethttp://n & 17.II.2008 & & & 1582 \\
\hline Giribethttp://n & 17.II.2008 & & & 556 \\
\hline G. Giribet http://n & 17.II.20 & & KJ87 & 583 \\
\hline $\mathrm{tp}: / / \mathrm{n}$ & 17.II. & & 85 & 584 \\
\hline$: / / \mathrm{n}$ & 15.I & & 86 & 585 \\
\hline$: / / \mathrm{m}$ & 15.I & 871371 & KJ87 & 586 \\
\hline Sarah L. Ihttp://n & 13.IV.2005 & -- & KF963 & 596.1 \\
\hline Benjamin http://n & 5.XI.2011 & -- & KJ871488 & KJ871605 \\
\hline$: / / \mathrm{m}$ & 7.XI.2011 & -- & -- & -- \\
\hline $\mathrm{tp}: / / \mathrm{n}$ & 9.IV.2011 & GQ912862.1 & GQ912708.1 & GQ912757.1 \\
\hline Michael Fht & 20.V.2 & -- & & \\
\hline Michael Fhttp://n & $20 . \mathrm{V}$. & -- & KJ87 & 602 \\
\hline C.J. Vink http://n & 4.X. & KJ871358 & KJ87 & 557 \\
\hline$: / / \mathrm{m}$ & $5 . X$ & & KJ871492 & \\
\hline C.J. Vink http://n & 5.X.2002 & & -- & \\
\hline N. Scharf http://n 1 & 19.XII.2010 & & & 1603 \\
\hline N. Scharf http://n 2 & 25.XII.2010 & KJ871353 & KJ871494 & KJ871604 \\
\hline David Lol http://n & 2002 & GQ912863.1 & GQ912711.1 & GQ912762.1 \\
\hline S. Velez http://n 2 & 24.XII.2009 & KJ871414 & KJ871495 & KJ871560 \\
\hline S. Velez http://n 3 & 31.XII.2009 & & -- & 1561 \\
\hline S. Velez http://n & 4.I.2010 & & & \\
\hline S. Velez $h$ & 5.I.2010 & & & 563 \\
\hline S. Velez http://n & 7.I.2( & & & 564 \\
\hline G. Giribethttp://n & 14.II.2008 & & & KJ871565 \\
\hline G. Giribethttp://n & 15.II.2008 & & & KJ871587 \\
\hline Gonzalo (http://n & 15.II.2008 & & KJ871501 & KJ871594 \\
\hline G. Giribethtt & 16.II.2008 & & & 71588 \\
\hline$: / / \mathrm{m}$ & 17.II.2008 & & & 71566 \\
\hline Gonza & 18.II.2008 & & & 1589 \\
\hline P. Paquin http://n & 21.II.2008 & & & \\
\hline Rosa Ferr http://n & 16.I.2014 & & & KJ871578 \\
\hline Rosa Ferr http://n & 12.I.2014 & & KJ871507 & KJ871576 \\
\hline Rosa Ferr http://n & 12.I.2014 & KJ870062 & KJ871508 & KJ871577 \\
\hline Rosa Ferr http://n & 12.I.2014 & KJ870056 & KJ871509 & KJ871568 \\
\hline Rosa Ferr http://n & 14.I.2014 & KJ870093 & KJ871510 & KJ871569 \\
\hline
\end{tabular}

Page 5 


\begin{tabular}{lcccc} 
& & & \multicolumn{2}{c}{ Sheet1 } \\
Rosa Ferr http://m & 14.I.2014 & KJ870083 & KJ871511 & KJ871570 \\
Rosa Ferr http://m & $15 . I .2014$ & KJ870071 & KJ871512 & KJ871590 \\
Rosa Ferr http://m & 20.I.2014 & KJ870080 & KJ871513 & KJ871591 \\
N. Scharf: http://m & $7 . I I I .2010$ & KJ871354 & KJ871514 & KJ871571 \\
J. Derraik http://m & $16 . I .2002$ & GQ912861 & KJ871515 & KJ871592 \\
& & -- & -- & JQ437120 \\
& & -- & JQ437009 & JQ437101 \\
& & -- & JQ437025 & JQ437135 \\
& & JQ437212 & JQ437026 & JQ437141 \\
& & JQ437213 & JQ437027 & JQ437143 \\
& & JQ437214 & JQ437028 & JQ437144 \\
& & JQ437210 & JQ437016 & JQ437117 \\
& & -- & JQ437049 & JQ437177
\end{tabular}

Page 6

http://www.publish.csiro.au/journals/is 